\title{
Ad-opleidingen: omvang en rendement
}

Citation for published version (APA):

Allen, J., Belfi, B., Bijlsma, I., Fouarge, D., \& Peeters, T. (2019). Ad-opleidingen: omvang en rendement. ROA. ROA Reports No. 004 https://doi.org/10.26481/umarep.2019004

Document status and date:

Published: 28/05/2019

DOI:

10.26481/umarep.2019004

Document Version:

Publisher's PDF, also known as Version of record

\section{Please check the document version of this publication:}

- A submitted manuscript is the version of the article upon submission and before peer-review. There can be important differences between the submitted version and the official published version of record.

People interested in the research are advised to contact the author for the final version of the publication, or visit the DOI to the publisher's website.

- The final author version and the galley proof are versions of the publication after peer review.

- The final published version features the final layout of the paper including the volume, issue and page numbers.

Link to publication

\footnotetext{
General rights rights.

- You may freely distribute the URL identifying the publication in the public portal. please follow below link for the End User Agreement:

www.umlib.nl/taverne-license

Take down policy

If you believe that this document breaches copyright please contact us at:

repository@maastrichtuniversity.nl

providing details and we will investigate your claim.
}

Copyright and moral rights for the publications made accessible in the public portal are retained by the authors and/or other copyright owners and it is a condition of accessing publications that users recognise and abide by the legal requirements associated with these

- Users may download and print one copy of any publication from the public portal for the purpose of private study or research.

- You may not further distribute the material or use it for any profit-making activity or commercial gain

If the publication is distributed under the terms of Article $25 \mathrm{fa}$ of the Dutch Copyright Act, indicated by the "Taverne" license above, 
Maastricht University

\section{Ad-opleidingen: omvang en rendement}

Jim Allen

Barbara Belfi

Ineke Bijlsma

Didier Fouarge

Tim Peeters

\section{ROA Rapport}

ROA-R-2019/4

Researchcentrum voor Onderwijs en Arbeidsmarkt | ROA Research Centre for Education and the Labour Market / ROA 


\section{Colofon}

(C) Researchcentrum voor Onderwijs en Arbeidsmarkt (ROA). Niets uit deze uitgave mag op enige manier worden verveelvoudigd zonder voorafgaande schriftelijke toestemming van de directeur van het ROA.

\section{Researchcentrum voor Onderwijs en Arbeidsmarkt}

Postbus 616

6200 MD Maastricht

$\mathrm{T}+31433883647$

$\mathrm{F}+31433884914$

secretary-roa-sbe@maastrichtuniversity.nl

www.roa.nl

School of Business and Economics

Maastricht University

\section{Vormgeving}

ROA secretariaat, Maastricht

ISBN: 978-90-5321-580-7

mei 2019 


\section{INHOUD}

\section{Voorwoord}

$1 \quad$ Inleiding

2 Ontstaan en situering Ad-opleidingen

3 Ad-opleidingen in perspectief

3.1 Aanbod

3.2 Studenten

3.3 Gediplomeerden

4 Uitkomsten van Ad

4.1 Aanpak

4.2 Subjectieve indicatoren

4.3 Objectieve indicatoren

6 Conclusie

Bijlage 


\section{VOORWOORD}

Een van de doelstellingen van de Nederlandse overheid is om een meer gevarieerd aanbod aan hogere beroepsopleidingen vorm te geven. Vanuit die gedachte is de Associate degree (Ad)-opleiding opgezet. Dit is een tweejarige hbo-opleiding die studenten opleidt tot niveau 5 van het Nederlands kwalificatieraamwerk (NLQF). Daarmee positioneert dit opleidingstype zich tussen mbo 4 en hbo-bachelor. Enerzijds richten Ad-opleidingen zich op mbo 4- of havo-gediplomeerden die willen doorstromen naar het hoger onderwijs om hun vakkennis te verbreden en te verdiepen, maar de stap naar een vierjarige hbo-bacheloropleiding te groot vinden. Anderzijds richten Ad-opleidingen (en dan met name de deeltijd en duale varianten) zich ook op werkenden die zich in het kader van een leven lang leren willen om- of bijscholen.

De eerste Ad-opleidingen werden in 2006 opgestart, en sinds 2018 hebben ze een volwaardige positie als hbo-opleiding. Tot op heden is er echter nog relatief weinig bekend over de kenmerken van de markt voor Ad-opleidingen, de kenmerken van deelnemers aan dergelijke opleidingen en de positionering van Ad-gediplomeerden op de arbeidsmarkt. Dit rapport tracht hier duidelijkheid in te scheppen.

Het onderzoek is tot stand gekomen als onderdeel van de HBO-Monitor ${ }^{1}$ (gefinancierd door de Vereniging Hogescholen) en het Project Onderwijs-Arbeidsmarkt², mede dankzij financiering van NRO (dossiernummer 405-17-900), UWV, S-BB en Randstad.

1 http://roa.sbe.maastrichtuniversity.nl/?portfolio=cedefop-mid-term-skills-supply-and-demand-forecast

2 http://roa.sbe.maastrichtuniversity.nl/?portfolio=poa-project-onderwijs-arbeidsmarkt-2 



\section{INLEIDING}

Om de kloof tussen het middelbaar beroepsonderwijs (mbo) en het hoger beroepsonderwijs (hbo) te verkleinen, werd in 2006 beslist om naast de hbo-bacheloropleiding ook tweejarige Associate degree (Ad)-opleidingen aan te bieden. Ondanks dat dit opleidingstype al geruime tijd bestaat, is echter nog maar weinig bekend over 1) de samenstelling van de instroom in Ad-opleidingen, 2) de doorstroom in het onderwijs naar en vanuit Ad-opleidingen en 3) de arbeidsmarktrelevantie en het rendement van Ad-opleidingen. Ad-gediplomeerden worden wel bevraagd in het kader van de HBO-Monitor, maar wegens een gebrek aan informatie over de representativiteit van deze data is hier tot op heden nog maar weinig mee gedaan in termen van landelijke of sectorale analyses. Ook andere bronnen zoals DUO-data en administratieve data zijn niet systematisch gebruikt voor het bepalen van de arbeidsmarktuitkomsten van Ad'ers.

Het voorliggende rapport wenst aan dit informatiegebrek tegemoet te komen, waardoor een beter beeld kan worden verkregen van de plaats die dit opleidingstype inneemt in het Nederlandse onderwijssysteem, en waardoor studiekiezers een beter geïnformeerde studiekeuze kunnen maken. Daarnaast poogt het rapport duidelijkheid te scheppen over de bruikbaarheid van de Ad-data in de HBO-Monitor, en een basis te leggen voor een verbeterde bevraging en rapportage van Ad-gediplomeerden die aan de HBO-Monitor deelnemen.

Ten eerste wordt in dit rapport antwoord gezocht op de vraag naar de compositie van de instroom in Ad-opleidingen. Momenteel is het nog onduidelijk wat de kenmerken zijn van de personen die voor dit opleidingstype kiezen, en in welke mate die kenmerken verschillen van andere opleidingsniveaus. Gaat het bijvoorbeeld voornamelijk om mannen of vrouwen, en om jongere of oudere studenten? Daarnaast is het relevant om in kaart te brengen welke vooropleiding Ad-instromers hebben gevolgd. Zijn het bijvoorbeeld hoofdzakelijk mbo 4 bol-gediplomeerden of havo-gediplomeerden, of betreft het vooral werkenden die een andere functie of een hoger loon wensen te verkrijgen? 
Verder heerst er nog onduidelijkheid over de arbeidsmarktuitkomsten (bijvoorbeeld de baankans en het loon) van Ad-opleidingen, en over de vraag in welke mate deze significant verschillen van opleidingen op een lager ( $\mathrm{mbo} 4 \mathrm{bol}$ ) of hoger (hbo-bachelor) niveau. Eerder onderzoek door het SEO Economisch Onderzoek uit 2015 gaf hierover reeds een reeks resultaten. Echter, dit onderzoek focuste slechts op de kortetermijnuitkomsten anderhalf jaar na afstuderen door uitsluitend gebruik te maken van surveydata. ${ }^{3}$ Met behulp van administratieve data wordt in het huidige onderzoek echter ook de arbeidsmarktpositie op langere termijn bestudeerd door de horizon uit te breiden naar vier jaar na afstuderen.

Het vraagstuk met betrekking tot de arbeidsmarktuitkomsten van Ad-opleidingen heeft verschillende facetten. In de eerste plaats gaat het om de vraag wat precies de baankansen van gediplomeerden van Ad-opleidingen zijn en wat zij verdienen, ofwel het rendement van deze opleidingen. Daarnaast hebben de arbeidsmarktuitkomsten betrekking op de kenmerken van de banen waarin de gediplomeerden terechtkomen, zoals het dienstverband en de gewerkte uren. In dit rapport gaan we daarbij steeds na in welke mate de baankansen, baankenmerken en het financiële rendement van Ad-opleidingen verschillen van die van mbo 4 bol- en hbo-bachelorgediplomeerden. Ten slotte geven we een beeld van de ontwikkeling van de arbeidsmarktuitkomsten tijdens de vroege loopbaan van de gediplomeerden (vier jaar na afstuderen).

Om deze onderzoeksvragen te beantwoorden wordt gebruik gemaakt van verschillende databronnen:

- Om het aanbod van Ad-opleidingen en Ad-gediplomeerden in beeld te brengen, maken we ten eerste gebruik van open data van de Dienst Uitvoering Onderwijs (DUO), die onderwijsgegevens registreert van studenten die ingeschreven zijn aan bekostigde Nederlandse onderwijsinstellingen.

- Ten tweede maken we gebruik van administratieve data op persoonsniveau. Hiervoor is een koppeling gemaakt tussen gegevens van de Gemeentelijke Basisadministratie Personen (GBA) en administratieve data van DUO. Die registerdata wordt vervolgens gekoppeld aan verdere microdata uit het Stelsel van Sociaalstatistische Bestanden (SSB) van het Centraal Bureau voor de Statistiek (CBS). Deze procedure geeft uiteindelijk een overzicht van de gediplomeerden uit de periode 2006-2016 en hun kenmerken. ${ }^{4}$ Met die administratieve data worden beschrijvende statistieken opgesteld en kunnen verschillende componenten van het rendement van Ad-opleidingen worden geschat. Subjectieve indicatoren kunnen echter niet uit deze data worden gehaald.

- Ten slotte wordt gebruik gemaakt van gegevens uit het SchoolverlatersInformatieSysteem (SIS) van het Researchcentrum voor Onderwijs en Arbeidsmarkt (ROA). Dit systeem bevat surveydata van schoolverlaters van onder meer het 
middelbaar beroepsonderwijs (op basis van de BVE-Monitor) en het hoger beroepsonderwijs (op basis van de HBO-Monitor). Die data gebruiken we om de kans op werkloosheid, studietevredenheidsaspecten, mogelijke competentiemismatches en de aansluiting naar niveau en richting van Ad-gediplomeerden in kaart te brengen, anderhalf jaar na afstuderen.

De opbouw van het rapport is als volgt. Het eerste hoofdstuk geeft een korte beschrijving van het ontstaan van de Ad-opleiding en haar wettelijke positie in het Nederlandse onderwijs. Daarna volgt een hoofdstuk met kerncijfers met betrekking tot Ad-studenten en Ad-gediplomeerden. Concreet gaat het daarbij om aantallen naar instelling, opleidingssector, opleidingsvorm (voltijd, deeltijd, duaal), geslacht en leeftijd. Waar mogelijk wordt de historische ontwikkeling getoond en worden de cijfers vergeleken met die van mbo 4 bol en hbo-bachelor. In dit hoofdstuk wordt eveneens de directe en indirecte instroom in Ad-opleidingen evenals het studierendement in beeld gebracht en uitgezet over de tijd. Hoofdstuk 4 behandelt vervolgens de uitkomsten van Ad-opleidingen. Hierbij wordt een onderscheid gemaakt tussen enerzijds tevredenheidsuitkomsten, en anderzijds arbeidsmarktuitkomsten. Met behulp van regressieanalyse wordt onder andere het rendement van Ad-opleidingen in termen van baankans en salaris twee en vier jaar na afstuderen geschat in vergelijking met mbo 4 bol en hbo-bachelor. Hoofdstuk 5 vergelijkt de Ad-informatie in de HBO-Monitor met de Ad-informatie in de administratieve data van DUO en het SSB. Het rapport sluit af met een conclusie waarin de belangrijkste resultaten nog eens op een rij worden gezet en bediscussieerd. 



\section{ONTSTAAN EN SITUERING AD- OPLEIDINGEN}

Een Ad-opleiding is een tweejarige initiële hbo-opleiding die studenten opleidt tot niveau 5 van het Nederlands kwalificatieraamwerk (NLQF). Daarmee positioneert dit opleidingstype zich tussen mbo 4 (NLQF 4) en hbo-bachelor (NLQF 6). Het is precies deze tussenpositie die maakt dat de Ad-opleiding in deze rapportage wordt afgezet tegen mbo 4 beroepsopleidende leerwerg (bol) en hbo-bachelor.

De invoering van de Ad past in de doelstelling van de Nederlandse overheid om een meer gevarieerd aanbod aan hogere beroepsopleidingen vorm te geven, ${ }^{5}$ en is voornamelijk gericht op mbo 4- of havo-gediplomeerden die willen doorstromen naar het hoger beroepsonderwijs om hun vakkennis te verbreden en te verdiepen, maar de stap naar een vierjarige hbo-bacheloropleiding (initieel) te groot vinden. Ook voor werkenden die zich willen om- of bijscholen kan een Ad-opleiding aantrekkelijk zijn. De studie is meer praktijkgericht dan de verwante hbo-bachelor, en sluit na afronding aan op een daaropvolgende hbo-bacheloropleiding.

Om de toegevoegde waarde van dit type opleidingen na te gaan gaf de Nederlandse overheid tussen 2006 en 2011 de mogelijkheid om Ad-opleidingen aan te bieden in vier pilotrondes. Na een positieve evaluatie besloot de overheid op 1 september 2013 om de Ad een definitieve plaats te geven in het hoger beroepsonderwijs, zodat de bestaande Ad-opleidingen hun pilotstatus kwijtraakten. Tussen 2012 en juli 2014 was het evenwel onmogelijk om nieuwe Ad-opleidingen te registreren. Op 1 januari 2018 trad de Wet Invoering Associate Degree-opleiding in werking, waardoor de Ad vanaf dat moment niet langer een programma binnen een vierjarige hbo-bachelor was, maar een op zichzelf staande opleiding binnen het hbo. Ondanks dat de Ad reeds sinds 2006 bestaat, is het opleidingstype nog relatief onbekend bij studenten, leraren en studieloopbaanbegeleiders. ${ }^{6}$

5 OCW (2011). Strategische Agenda Hoger Onderwijs, Onderzoek en Wetenschap: Kwaliteit in verscheidenheid, Den Haag.

6 Voor meer informatie over de (on)bekendheid van de Ad, zie SEO Economisch Onderzoek (2015). Klaar voor de groei? Monitor uitrol Associate degree, Amsterdam. 



\section{AD-OPLEIDINGEN IN PERSPECTIEF}

Dit hoofdstuk geeft achtereenvolgens een beeld van de instroom van Ad-studenten en uitstroom van Ad-gediplomeerden. Dat dubbele perspectief is relevant omdat de instroom van studenten een indicatie geeft van het potentiële aanbod van toekomstig gediplomeerden. Het hoofdstuk begint met een overzicht van de verdeling van de Ad-studenten over de verschillende onderwijsinstellingen. Daarna wordt de historische evolutie van het aantal Ad'ers voorgesteld en uitgesplitst naar zowel opleidingsvorm (voltijd, deeltijd, duaal) als onderwijssector. Vervolgens wordt nader ingegaan op de kenmerken van Ad'ers in termen van leeftijd en geslacht. Telkens worden daarbij de Ad'ers vergeleken met personen die een mbo 4 bol- of hbo-bacheloropleiding volgen. Daarbij wordt de keuze gemaakt om Ad-opleidingen langs mbo-zijde enkel te vergelijken met mbo 4 bol, aangezien bol-opleidingen in tegenstelling tot de beroepsbegeleidende leerweg (bbl)-opleidingen sterker gericht zijn op het volgen van een eventuele vervolgopleiding in het hoger beroepsonderwijs.

\subsection{Aanbod}

Zoals blijkt uit Figuur 1 wordt het Ad-aanbod gedomineerd door slechts enkele onderwijsinstellingen. Met name vier hogescholen blijken verantwoordelijk voor bijna twee derde van het aantal eerstejaars Ad-studenten. Hogeschool Rotterdam kende in 20172018 met bijna 30\% van de eerstejaars Ad-studenten veruit de grootste Ad-instroom. Die instroom was bovendien groter dan die van de twee eerstvolgende hbo-instellingen samen: Avans Hogeschool en Stenden Hogeschool. Verder behoort ook de Christelijke Hogeschool Ede tot de vier grootste aanbieders van Ad-onderwijs. Ten slotte zijn er vijf instellingen die in 2017-2018 elk minder dan 0,5\% van de eerstejaars Ad-inschrijvingen kenden, namelijk de Hogeschool van Amsterdam, HZ University of Applied Sciences, Hogeschool Utrecht, ArtEZ en Saxion Hogeschool.

De relatief grote omvang van de Ad-instroom bij de Hogeschool Rotterdam heeft ermee te maken dat deze onderwijsinstelling reeds vroeg heeft beslist om hun Ad-opleidingen onder te brengen in de Rotterdam Academy. De Ad-opleidingen die daar aangeboden worden zijn ontwikkeld in samenwerking met de Rotterdamse ROC's Zadkine en het Albeda College. Bovendien zijn deze Ad-programma's niet afgeleid van bestaande 
hbo-bacheloropleidingen, maar zijn ze ontwikkeld in samenspraak met werkgevers en hebben ze dus een sterke link met de vraag vanuit de arbeidsmarkt.

FIGUUR 1 Aandeel eerstejaars Ad-studenten naar instelling (2017-2018)

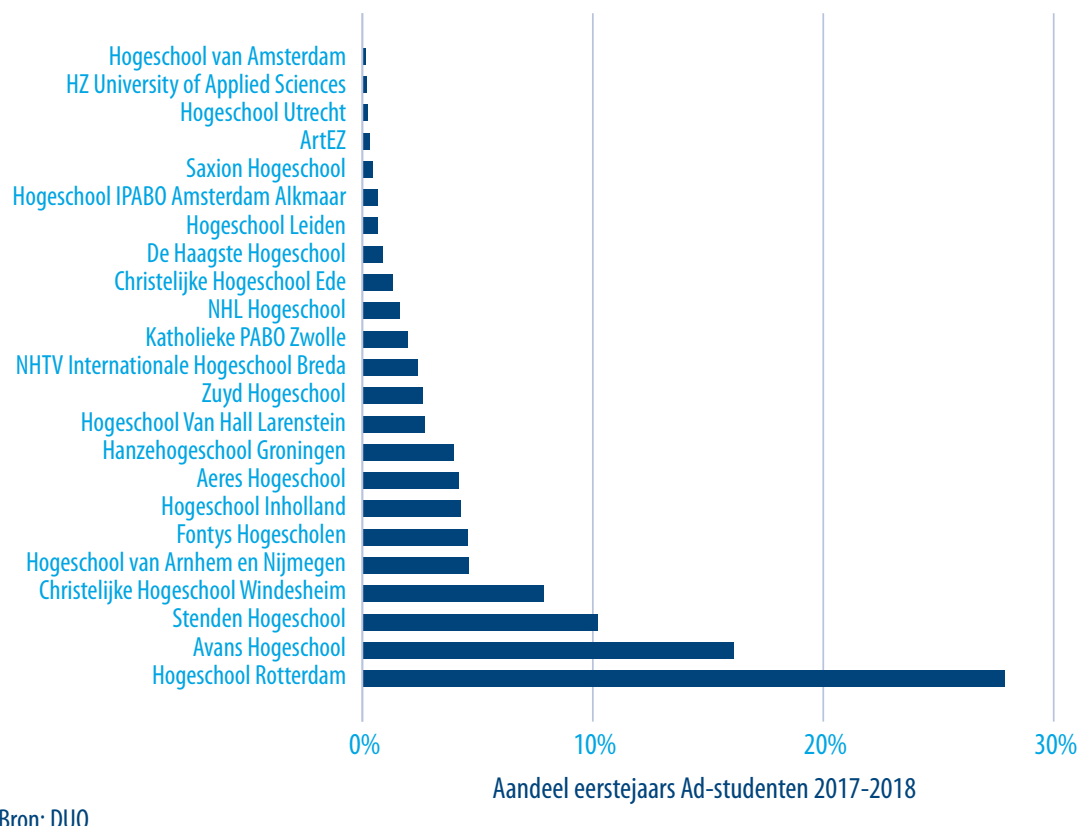

\subsection{Studenten}

\section{Aantallen naar opleidingsvorm}

In het schooljaar 2016-2017 waren er iets meer dan 4.300 eerstejaarsstudenten die zich hadden ingeschreven in een Ad-opleiding. Dit blijkt uit Figuur 2, die de evolutie van het aantal eerstejaars Ad-studenten naar opleidingsvorm tussen 2006 en 2017 laat zien. Wat opvalt is dat het aantal eerstejaars Ad'ers sinds 2006 vrij consequent is toegenomen. Dit zou, naast een teken van de groeiende populariteit van dit opleidingstype, ook een indicatie kunnen zijn van een toenemende bekendheid ervan. Sinds 2010-2011 is het aantal eerstejaarsstudenten in Ad-opleidingen met 40\% gestegen.

Verder valt op dat ongeveer de helft van de eerstejaarsstudenten een Ad-opleiding volgt in een deeltijd of duaal programma. De relatief grote omvang van Ad-deeltijd en -duaal (in vergelijking met hbo-bachelor, zie Figuur 3) suggereert dat de beweegredenen om een Ad-opleiding te volgen verschillen tussen studenten. Een deel lijkt een Ad-opleiding te volgen als initiële opleiding en een ander deel lijkt de opleiding later in de loopbaan 
aan te vangen, in combinatie met een betaalde baan. De deelname van deze laatste groep suggereert dat de Ad een belangrijke rol speelt bij een leven lang leren.

FIGUUR 2 Aantal eerstejaars Ad-studenten naar opleidingsvorm (2006-2017)

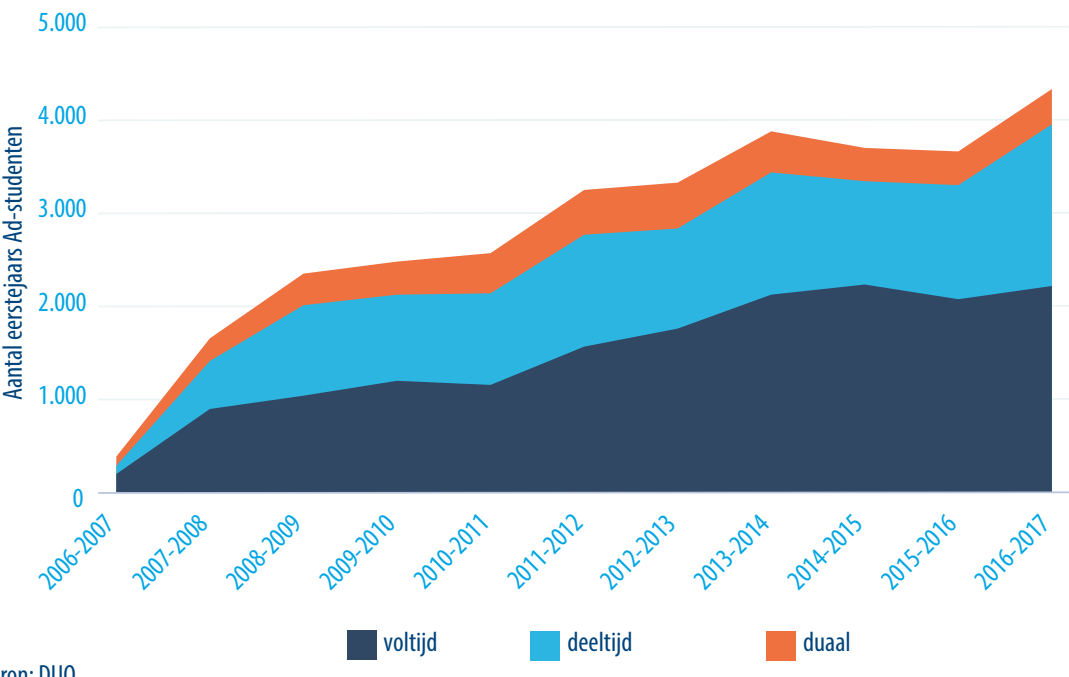

Bron: DUO

Ondanks dat het aantal eerstejaarsstudenten dat een Ad-opleiding volgt de laatste twee jaar flink is toegenomen, is hun aandeel in het hbo als geheel nog steeds beperkt. Een vergelijking van Figuur 2 met Figuur 3, die het aantal eerstejaars hbo-bachelorstudenten naar opleidingsvorm weergeeft, toont dat Ad'ers in 2017-2018 slechts 3,3\% uitmaakten van het totaal aantal hbo'ers. Dat beperkte aandeel is wellicht voor een groot deel een gevolg van de relatieve onbekendheid van de Ad. Verder blijkt dat het aandeel van eerstejaars hbo-bachelorstudenten dat een deeltijd of duaal traject volgt aanzienlijk kleiner is dan bij Ad'ers. Dit laatste is nog meer het geval bij studenten in een mbo 4 bol-opleiding, waar de deeltijd component te verwaarlozen is (zie Figuur X in bijlage). 
FIGUUR 3 Aantal eerstejaars hbo-bachelorstudenten naar opleidingsvorm (2006-2017)

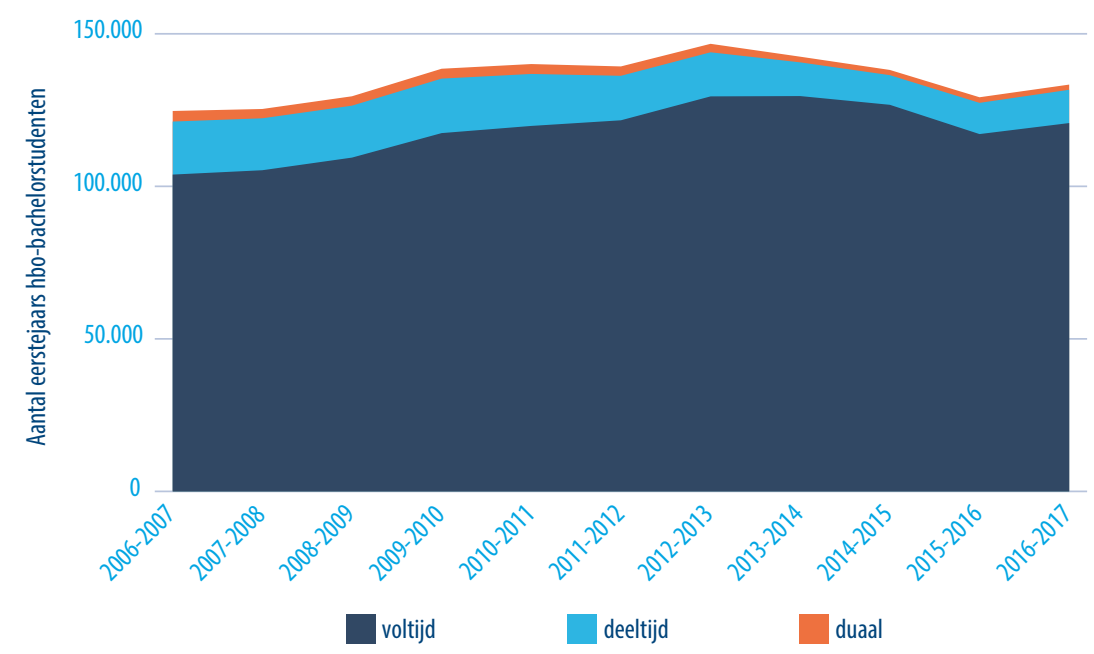

Bron: DUO

\section{Opleidingssector}

Naast een uitsplitsing naar instelling en opleidingsvorm, kan de instroom van studenten in opleidingen eveneens worden uitgesplitst naar opleidingssector. Figuur 4 laat dit zien voor eerstejaars Ad-studenten. Opvallend is dat bijna de helft van de studenten een Ad-opleiding volgt binnen de sector Economie. Daarnaast zijn ook de sector Zorg en Welzijn en de sector Maatschappij, Taal en Kunst met respectievelijk 15\% en 10\% en van de eerstejaars Ad-studenten vrij populair. Opleidingssectoren die daarentegen het minst worden gekozen zijn Agrarisch en Milieu, Onderwijs en Openbaar Bestuur en Juridisch. 
FIGUUR 4 Aantal eerstejaars Ad-studenten naar opleidingssector (2016-2017)

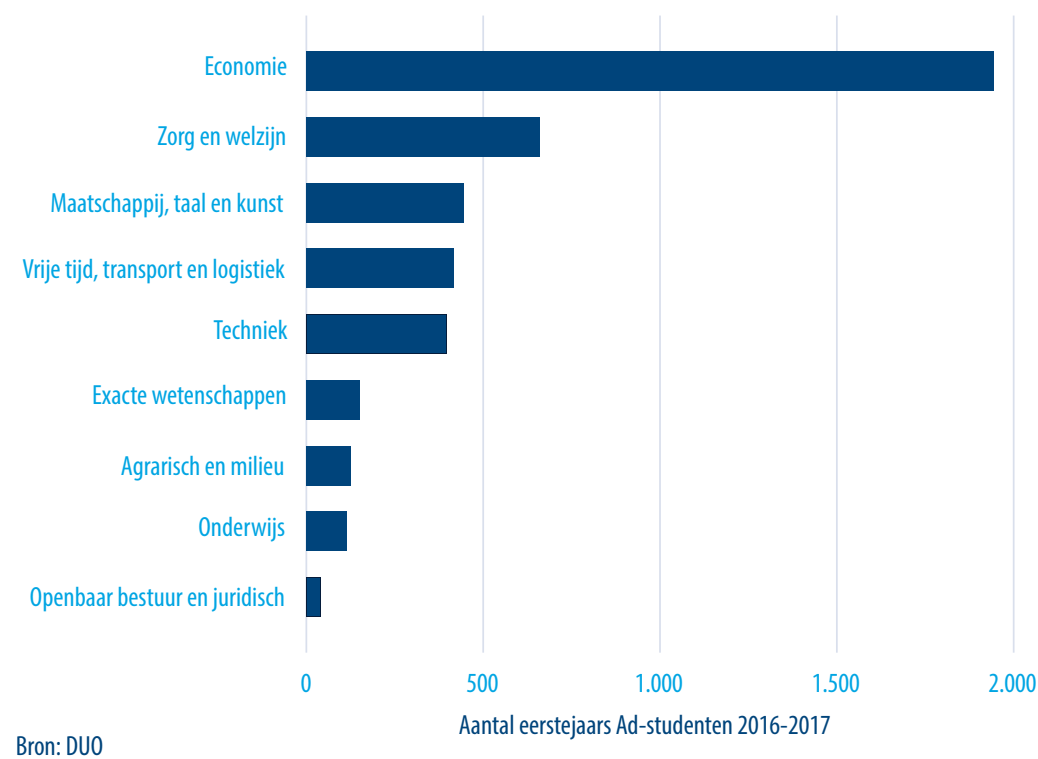

Zoals blijkt uit Figuur 5 komt de verdeling van eerstejaars Ad-studenten in zekere mate overeen met de verdeling van eerstejaars hbo-bachelorstudenten. De sectoren Economie, Zorg en Welzijn en Maatschappij, Taal en Kunst worden namelijk ook door eerstejaars hbo-bachelorstudenten het vaakst gevolgd. De sector Economie neemt daarbij bijna een vierde van het totaal aantal inschrijvingen voor zijn rekening. Het voornaamste verschil met de verdeling binnen Ad-opleidingen, is echter dat hbo-bachelorstudenten beduidend vaker ingeschreven zijn in de zorgsector en de onderwijssector. 


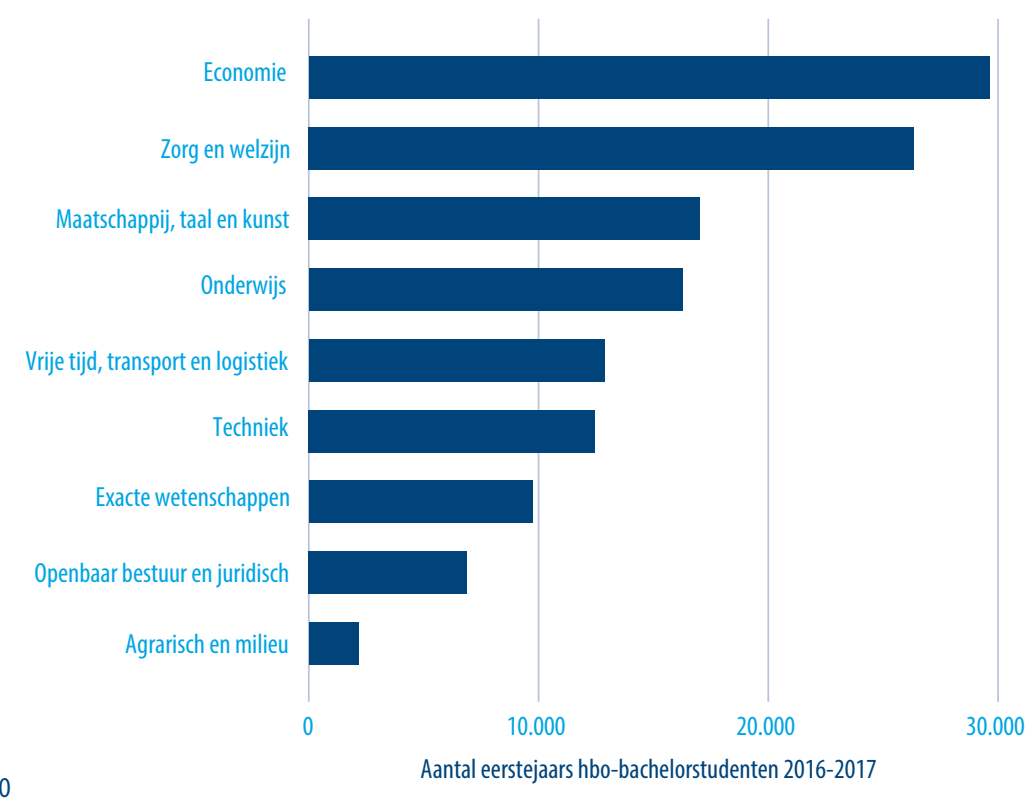

Bron: DUO

Aantal eerstejaars hbo-bachelorstudenten 2016-2017

Uit Figuur Y in de bijlage, die het totaal aantal mbo 4 bol-studenten weergeeft naar opleidingssector, blijkt ten slotte dat ook binnen dit opleidingsniveau de sectoren Economie en Zorg en Welzijn relatief groot zijn. In vergelijking met de Ad'ers is de sector Zorg en Welzijn onder mbo 4 bol-studenten echter aanzienlijk populairder.

\section{Instroom in Ad}

Naast een beeld van de opleidingen en richtingen waarvoor Ad-studenten hoofdzakelijk kiezen, is het relevant om na te gaan vanuit welk opleidingsniveau en sociaal-economische positie de eerstejaarsstudenten instromen. Deze paragraaf beschrijft daarom de samenstelling van de vooropleiding van Ad- en hbo-bachelorstudenten door de tijd heen, en hoe deze verschilt naar opleidingsvorm. Daarbij wordt eveneens onderzocht in welke mate deze eerstejaarsstudenten instromen vanuit het onderwijs of een werksituatie. Personen die vóór hun inschrijving in de Ad reeds een hogere opleiding hebben gevolgd worden hierbij eveneens tot eerstejaars Ad-studenten gerekend.

Het linkerpaneel van Figuur 6 toont de procentuele samenstelling van de voltijd Ad-instroom naar opleidingsniveau voor de jaren 2006-2015. Het rechterpaneel doet hetzelfde voor de instroom van voltijd hbo-bachelorstudenten. De vooropleiding van de instromers wordt daarbij gedefinieerd als het hoogst behaalde diploma vóór de inschrijving in de Ad of hbo-bachelor. Telkens is ook aangegeven in welke mate eerstejaars voltijd Ad-en hbo-bachelorstudenten één jaar voordat zij zich inschreven werkend 
waren. Daarnaast is ook een categorie "niet-werkenden" opgenomen, die personen bevat die een werkloosheidsuitkering, bijstandsuitkering, pensioenuitkering, ziekte/ AO-uitkering of overige sociale uitkering ontvangen. Verder vallen ook meewerkende gezinsleden in deze categorie, evenals personen die niet werken, noch studeren, noch een uitkering krijgen.

De instroom in voltijd Ad-opleidingen bestaat voor de helft uit mbo 4-gediplomeerden, en voor bijna $20 \%$ uit gediplomeerden van havo/vwo. Bij voltijd hbo-bacheloropleidingen is een tegengesteld patroon zichtbaar: hierbij stroomt slechts $20 \%$ in vanuit een mbo 4-opleiding, en vormt de instroom vanuit havo/vwo met bijna 50\% de grootste categorie. Het beduidend grotere aandeel Ad-instromers met mbo 4 als vooropleiding wijst op de mogelijke relevantie van de Ad voor het bevorderen van de aansluiting tussen mbo 4 en het hoger onderwijs. Het aandeel van mbo 4-gediplomeerden dat aan een Ad begint lijkt de laatste jaren bovendien toe te nemen. Daarnaast valt op dat de Ad-instroom van personen met een hbo- of wo propedeuse zeer beperkt is, en de Ad dus niet in de eerste plaats voortijdig uitvallende hbo'ers of wo'ers aantrekt.

FIGUUR 6 Voorgeschiedenis van eerstejaars voltijd Ad- en hbo-bachelorstudenten (2006-2015)
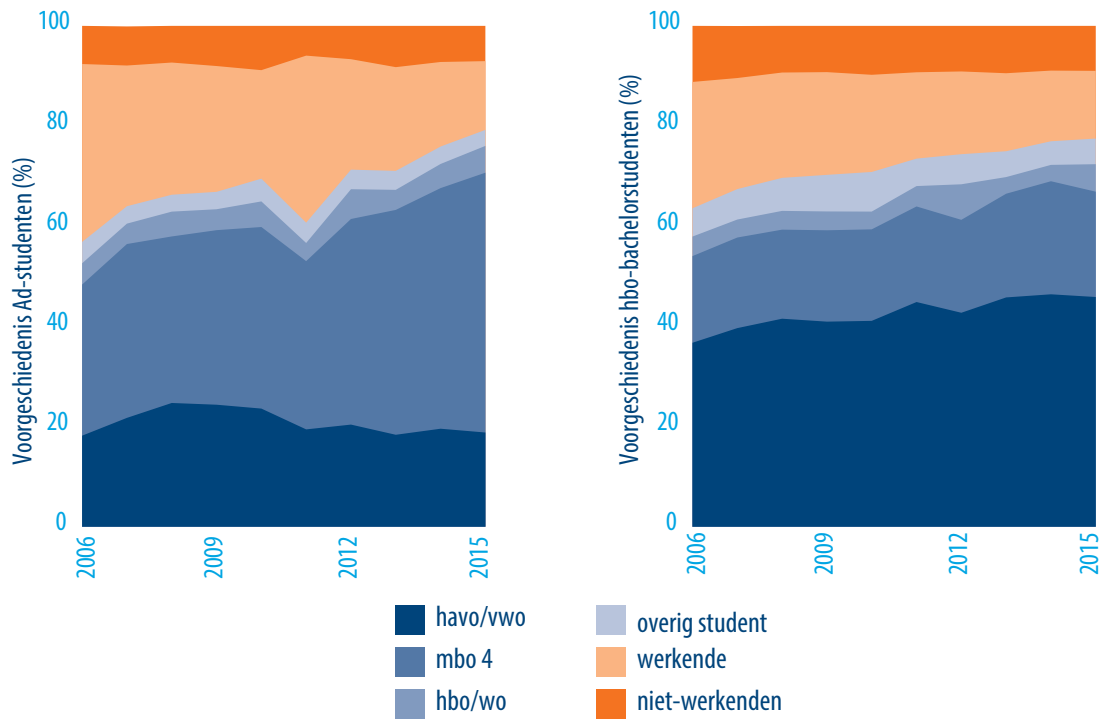

Bron: DUO/SSB

Verder blijkt uit de figuur dat er niet zo veel verschil is tussen de voorafgaande sociaaleconomische status van instromende studenten in een voltijd Ad en hbo-bacheloropleiding. In beide gevallen bestond de instroom in 2015 voor bijna $80 \%$ uit personen die rechtstreeks vanuit een vooropleiding kwamen. Bovendien is dit percentage zowel bij de voltijd Ad als voltijd hbo-bachelor gestegen sinds 2006. Werkenden die besloten om 
een voltijd Ad of hbo-bachelor te volgen, maakten in 2006 namelijk nog $40 \%$ van de eerstejaarsstudenten uit, tegenover ongeveer 15\% in 2015.

Zoals blijkt uit Figuur 7 verschilt de samenstelling van de vooropleiding van instromers in deeltijd Ad- en hbo-bacheloropleidingen aanzienlijk van die van voltijd instromers. Wel lijkt de instroom in deeltijd opleidingen sterker op elkaar dan de instroom in voltijd opleidingen, wat suggereert dat min of meer dezelfde groep mensen door deze opleidingsvorm wordt aangesproken. Opvallend is dat de deeltijd Ad-instroom voor meer dan de helft uit werkenden bestaat, en slechts voor een derde uit personen die rechtstreeks uit het onderwijs komen. Ook onder deeltijd hbo-bachelorstudenten is het aandeel van werkenden het grootst, doch iets kleiner dan onder deeltijd Ad'ers. In beide gevallen is het aandeel van instromers uit het onderwijs wel gestegen sinds 2006 .

De groep die rechtstreeks vanuit het onderwijs naar een deeltijd Ad-opleiding doorstroomt, bestaat net als bij de voltijd Ad-instroom voor ongeveer de helft uit mbo 4-gediplomeerden. Het havo/vwo-aandeel is echter beduidend kleiner, hoewel het een stijgende trend vertoont. Verder laat de figuur zien dat de deeltijd hbo-bachelor relatief populair is bij personen die reeds een hbo- of wo-bachelordiploma hebben behaald. Van de deeltijd hbo-bachelorstudenten heeft namelijk ongeveer $10 \%$ al een hbo- of wo-diploma op zak.

FIGUUR 7 Voorgeschiedenis van eerstejaars deeltijd Ad- en hbo-bachelorstudenten (2006-2015)
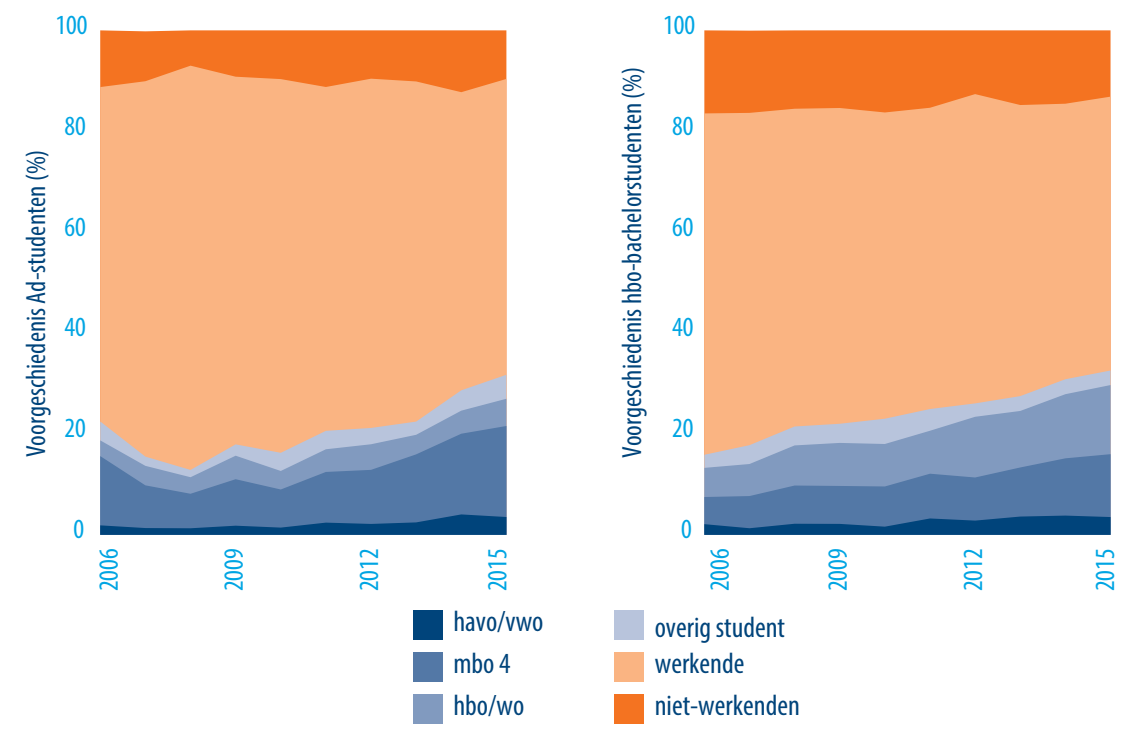

Bron: DUO/SSB

De duale Ad-instroom, weergegeven in Figuur 8, lijkt sterk op de deeltijd Ad-instroom, hoewel het aandeel van werkenden iets kleiner is en het aandeel instromers vanuit het 
onderwijs iets groter. Duale Ad-opleidingen worden dus minder vaak door werkenden gevolgd dan de deeltijd varianten (zie ook Figuur 2). Bovendien komt ook hier meer dan de helft van de rechtstreekse instromers vanuit het onderwijs uit een mbo 4-opleiding, en groeit dit aandeel door de tijd heen. De instroom in duale hbo-bacheloropleidingen verschilt daarentegen wat meer van de deeltijd instroom, aangezien het aandeel werkenden hier aanzienlijk kleiner is, en de meerderheid rechtsreeks instroomt vanuit het onderwijs.

FIGUUR 8 Voorgeschiedenis van eerstejaars duale Ad- en hbo-bachelorstudenten (2006-2015)
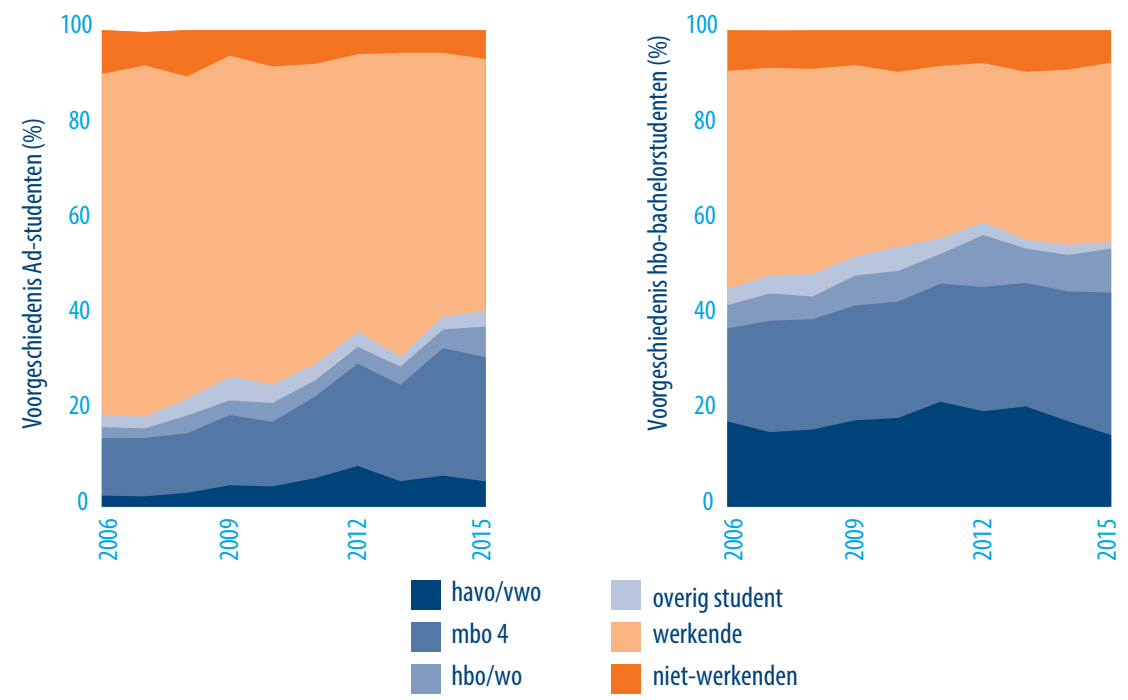

Bron: DUO/SSB

\section{Studierendement Ad}

Slechts een gedeelte van de studenten die starten met een Ad- of hbo-bacheloropleiding maakt deze opleiding ook daadwerkelijk af. De instroomcijfers uit de vorige paragraaf worden hier daarom aangevuld met cijfers over de uitval. Figuur 9 toont het percentage van de Ad-en hbo-bachelorinstroom studenten dat aan de opleiding begint maar deze niet afmaakt. Dergelijke uitvallers zijn in de administratieve data geïdentificeerd als personen die hun opleiding na vier jaar (in het geval van een Ad) of zes jaar (in het geval van een hbo-bachelor) niet hebben afgemaakt.

Twee op de drie personen die tussen 2006 en 2010 aan een voltijd Ad begonnen stopten vroegtijdig met de studie. Daarmee bedroeg het studierendement van de voltijd Ad ongeveer $34 \%$. Dat is aanzienlijk minder dan het studierendement van bijna $50 \%$ van de voltijd hbo-bachelor. In 2011 nam de uitval van voltijd Ad-studenten echter fors af tot $58 \%$, waardoor het studierendement van de voltijd Ad enigszins convergeerde naar dat 
van de voltijd hbo-bachelor. De dunne oranje lijn geeft aan dat $19 \%$ van de studenten die stopten met een voltijd Ad hierna overstapten naar een andere opleiding, wat 5 procentpunten meer is dan onder voltijd hbo'ers.?

In tegenstelling tot voltijd Ad-studenten maken Ad'ers uit deeltijd en duale opleidingen vaker hun studie af dan hbo-bachelorstudenten uit deeltijd of duale programma's. Van de deeltijd en duale Ad'ers die in 2011 instroomden behaalde namelijk iets meer dan de helft een diploma, vergeleken met ongeveer $45 \%$ van de deeltijd en duale hbo-bachelorstudenten. Personen die stoppen met een deeltijd of duale Ad stappen bovendien iets frequenter over naar een andere opleiding dan deeltijd en duale hbo'ers.

FIGUUR 9 Percentage uitval van Ad- (2006-2011) en hbo-bachelorstudenten (2006-2009) naar opleidingsvorm

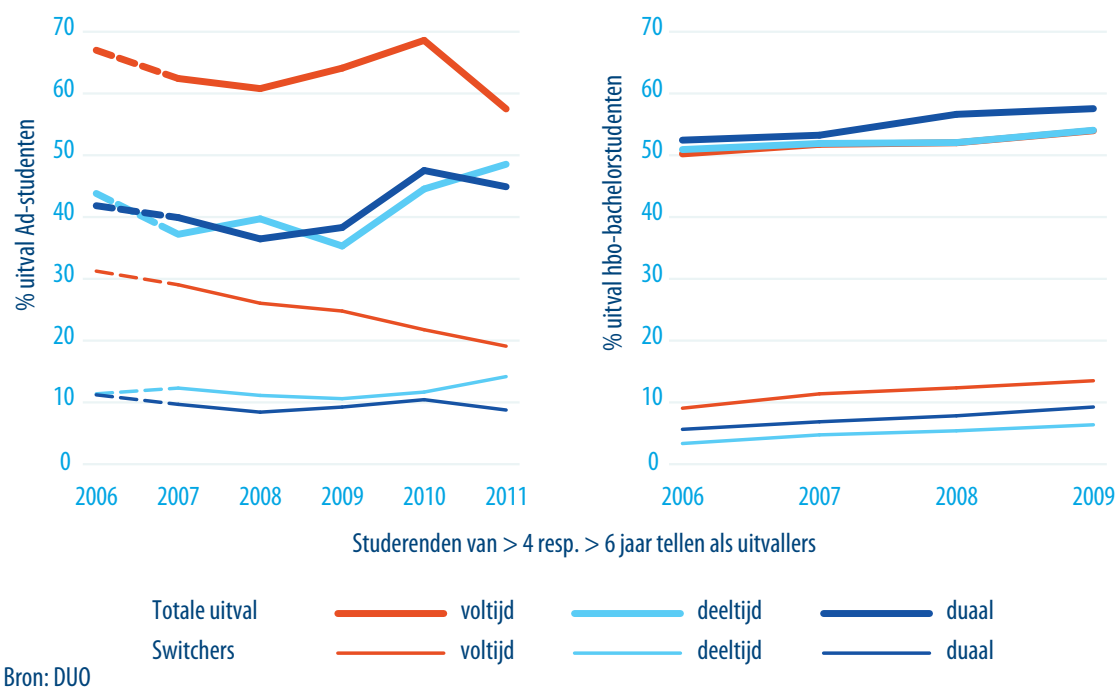

\subsection{Gediplomeerden}

Om meer inzicht te krijgen in de verschillen tussen wie aan een Ad begint en wie er daadwerkelijk afstudeert, worden de instroomcijfers uit de vorige paragraaf hier aangevuld met cijfers over uitstroom. Opnieuw worden de aantallen naar opleidingsvorm en -sector beschreven, en vergeleken met hbo-bachelor en mbo 4 bol. Daarnaast wordt ingegaan op de kenmerken van Ad-gediplomeerden in termen van leeftijd en geslacht.

7 Een diepere analyse toont bovendien dat slechts een zeer kleine fractie van de overstappende Ad'ers opnieuw aan een Ad begint. 
Figuur 10 toont het aantal Ad-gediplomeerden naar opleidingsvorm. Hieruit blijkt dat het aantal Ad-gediplomeerden tussen 2007 en 2015 jaarlijks toenam. Sinds schooljaar 2015-2016 daalde het aantal Ad-gediplomeerden echter voor het eerst, en in 2016-2017 studeerden er nog ongeveer 1800 personen met een Ad-diploma af. Een vergelijking van de Ad-cijfers met de verdeling naar opleidingsvorm binnen hbo-bachelor en mbo 4 bol, zoals voorgesteld in Figuur 11 en Figuur 12, wijst op een belangrijk verschil met deze opleidingsniveaus. Afgestudeerden van een hbo-bacheloropleiding volgden hoofdzakelijk een voltijd programma, en slechts een kleine fractie koos voor een deeltijd of duale opleidingsvorm. Hetzelfde geldt voor de verdeling binnen mbo 4 bol-opleidingen. De uitstroom van Ad-gediplomeerden bestaat daarentegen voor bijna de helft uit personen die een deeltijd of duaal traject volgden. Dit is een gevolg van de vaststelling dat Ad-opleidingen vaker gekozen worden door personen die reeds werkzaam zijn. ${ }^{8}$

FIGUUR 10 Aantal Ad-gediplomeerden naar opleidingsvorm (2007-2017)

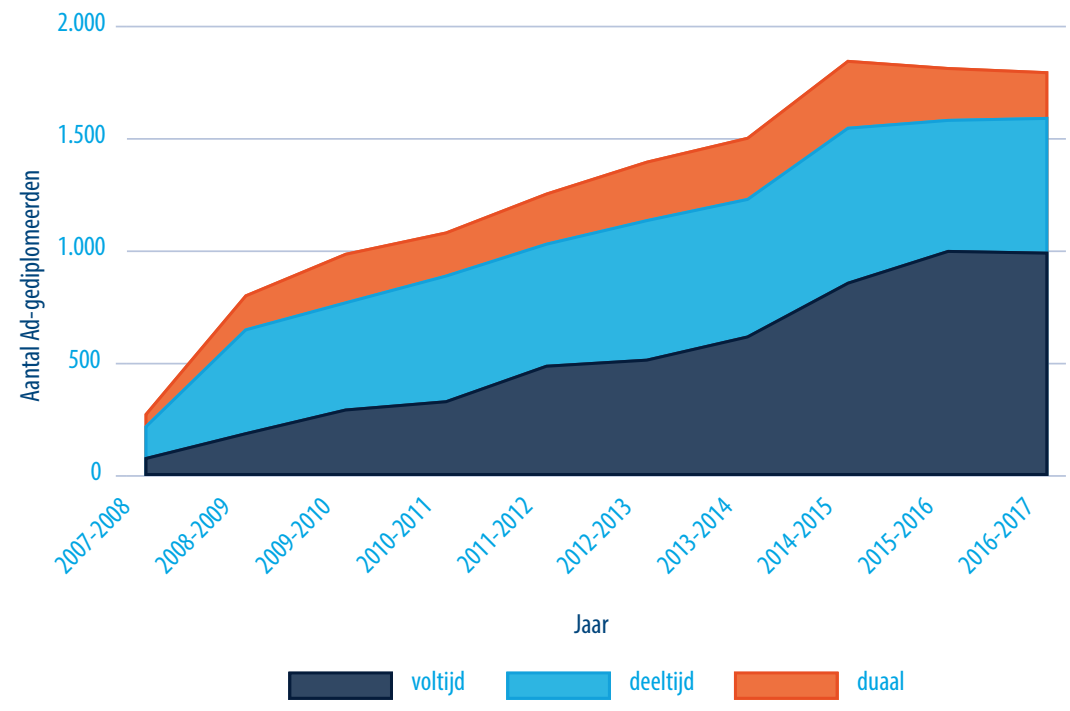

Bron: DUO

8 SEO Economisch Onderzoek (2015). Klaar voor de groei? Monitor uitrol Associate degree, Amsterdam. 
FIGUUR 11 Aantal hbo-bachelorgediplomeerden naar opleidingsvorm (2006-2017)

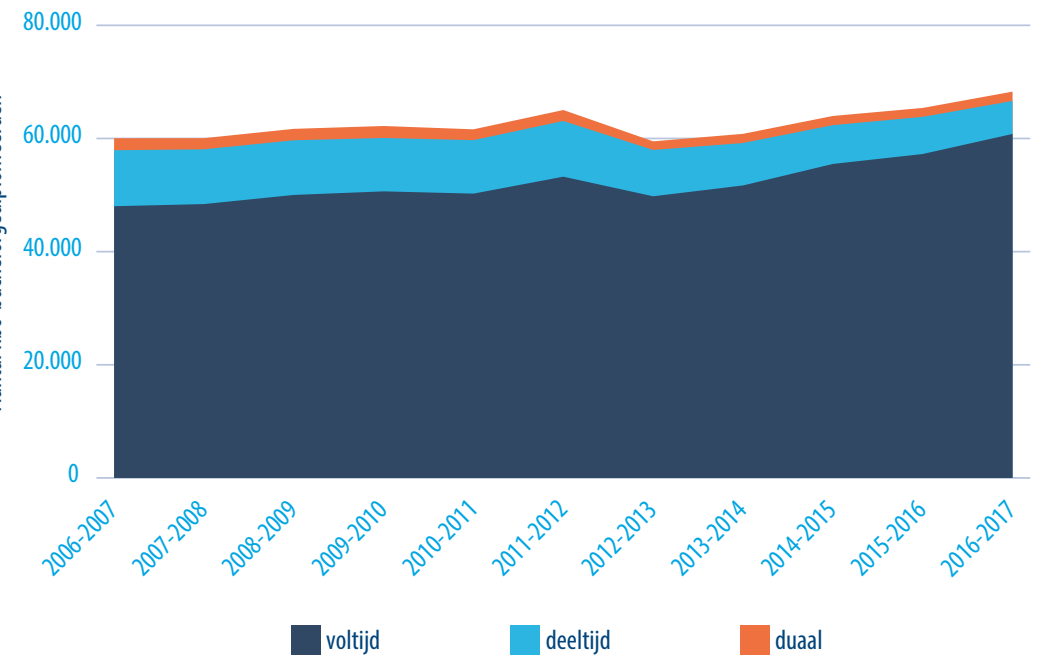

Bron: DUO

Figuur 11 wijst daarnaast ook op een overeenkomst tussen de uitstroom van Ad- en hbobachelorgediplomeerden. Het aandeel van afgestudeerden van voltijd opleidingen is bij beide opleidingsniveaus namelijk door de tijd heen toegenomen. Waar in 2009 slechts $30 \%$ van de Ad-gediplomeerden een voltijd opleiding had gevolgd, was dat aandeel in 2017 gestegen tot 55\%. Bij hbo-bacheloropleidingen nam de uitstroom van voltijd gediplomeerden in dezelfde periode toe van $81 \%$ naar $88 \%$. Bij mbo 4 bol-opleidingen is het aandeel van de gediplomeerden uit een deeltijd programma over de jaren heen afgenomen tot slechts 0,2\% in 2017. 
FIGUUR 12 Aantal mbo 4 bol-gediplomeerden naar opleidingsvorm (2006-2017)

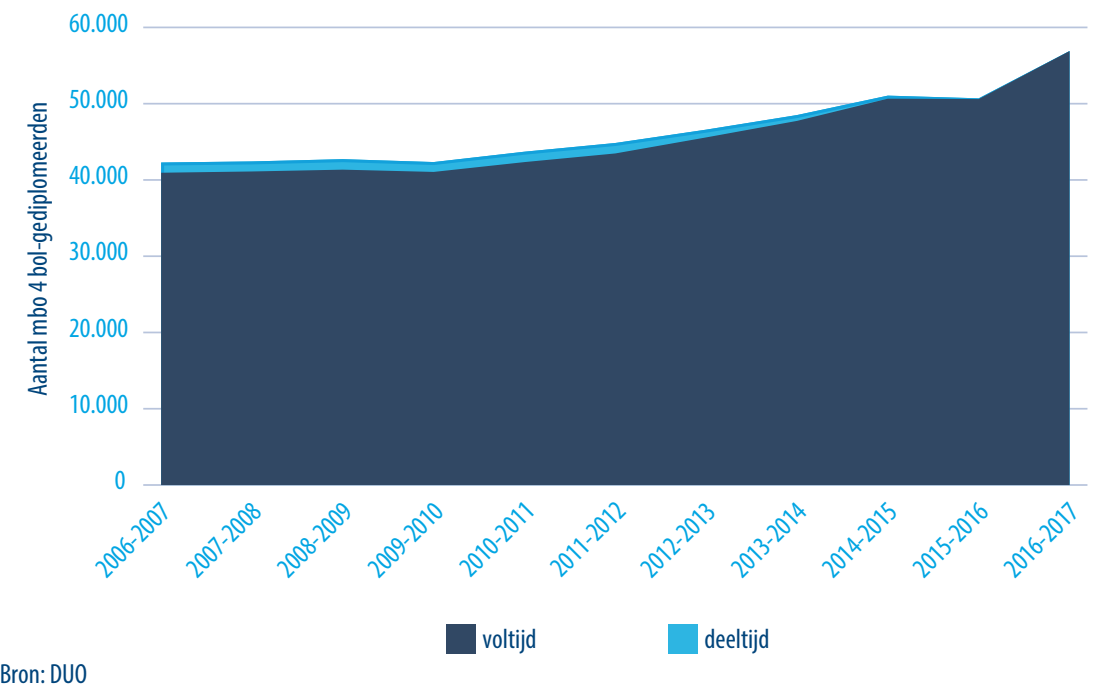

\section{Opleidingssector}

Net als de instroom van eerstejaarsstudenten kan de uitstroom van gediplomeerden worden voorgesteld naar opleidingssector. Overeenkomstig met de instroomcijfers volgde bijna de helft van de Ad-gediplomeerden een richting binnen de sector Economie (zie Figuur 13). Daarnaast kenden ook de sectoren Vrije Tijd, Transport en Logistiek en Zorg en Welzijn relatief veel afgestudeerden. Alumni van Ad-opleidingen uit de onderwijssector, de Exacte Wetenschappen of de sector Agrarisch en Milieu komen dan weer beduidend minder vaak voor. 
FIGUUR 13 Aantal Ad-gediplomeerden naar opleidingssector (2016-2017)

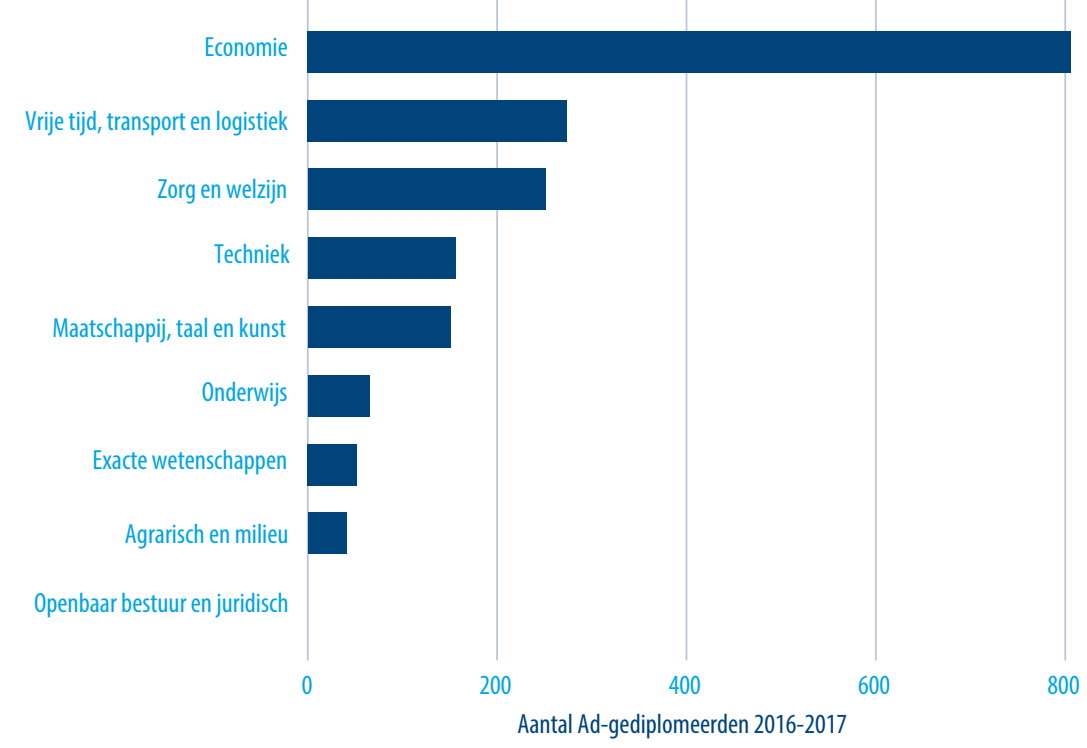

Bron: DUO

Zoals blijkt uit Figuur 14 en Figuur 15, is Economie ook binnen hbo-bachelor en mbo 4 bol een belangrijke sector. Het grootste aantal gediplomeerden geldt echter bij beide opleidingsniveaus voor de sector Zorg en Welzijn. Daarmee is deze sector aanzienlijk groter dan onder Ad-gediplomeerden.

FIGUUR 14 Aantal hbo-bachelorgediplomeerden naar opleidingssector (2016-2017)

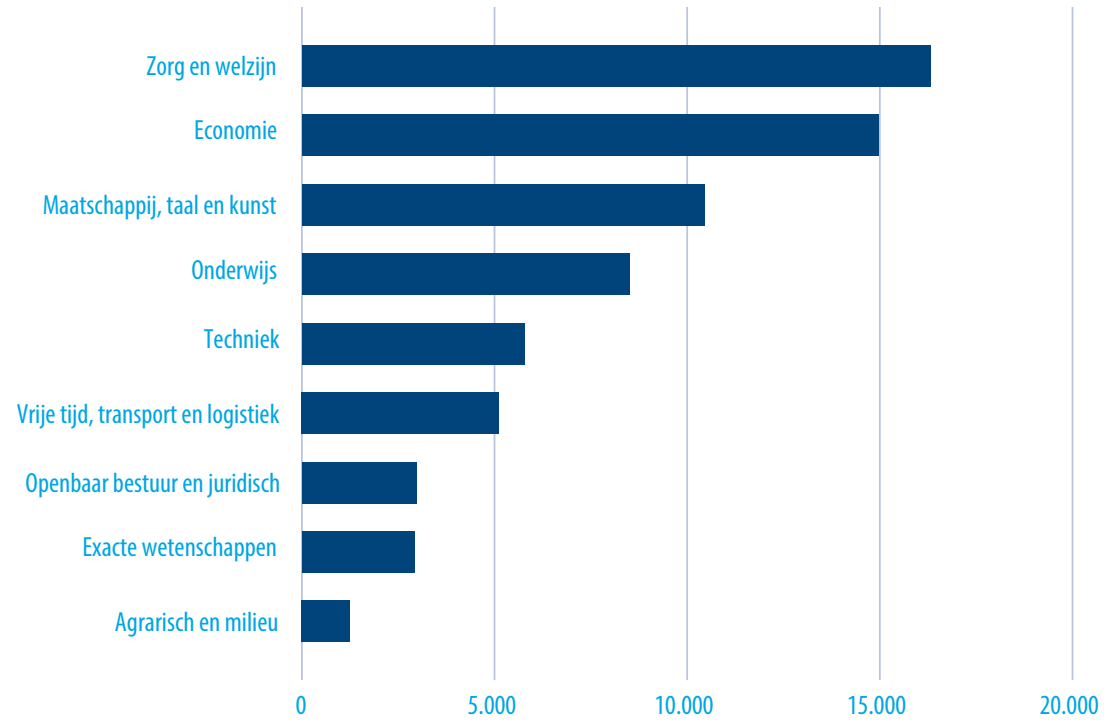

Bron: DUO

Aantal hbo-bachelorgediplomeerden 2016-2017 


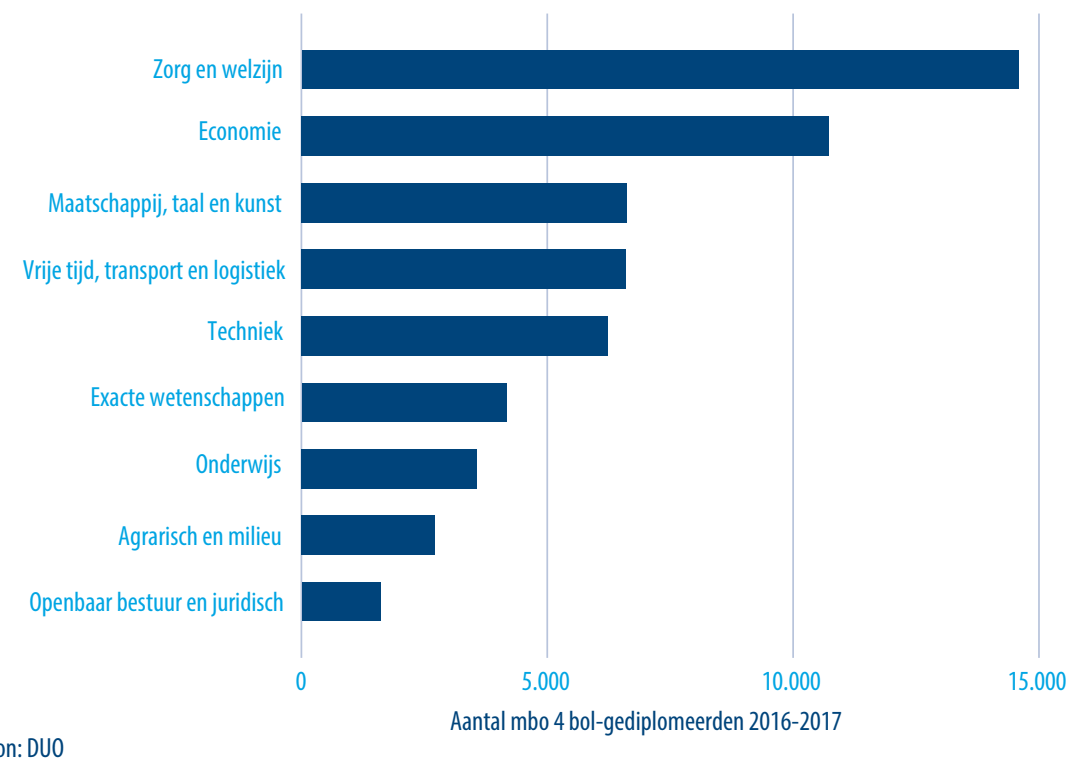

\section{Kenmerken van de uitgestroomde gediplomeerden}

De cijfers uit de vorige paragraaf gaven wel een beeld van de omvang van de Ad-uitstroom, maar gaven nog geen verdere informatie over de kenmerken van de gediplomeerden die ervoor kozen om dit opleidingstype te volgen. Deze paragraaf geeft een beeld van de eigenschappen van Ad-gediplomeerden in termen van zowel leeftijd als geslacht.

Figuur 16 toont het percentage vrouwen in de Ad-uitstroom. Tussen 2012 en 2016 steeg het percentage vrouwelijke Ad-gediplomeerden van 51\% naar 55\%. Vooral tussen 2014 en 2015 steeg het aandeel vrouwen relatief sterk. Een gevolg van deze relatieve toename is dat de Ad-uitstroom hiermee meer in lijn is komen te liggen met de percentages vrouwelijke hbo-bachelor- en mbo 4 bol-gediplomeerden. Deze twee laatste percentages zijn tussen 2012 en 2016 relatief constant gebleven op ongeveer 57\%. De toename van het percentage vrouwelijke Ad-afgestudeerden is het grootst onder afgestudeerden van een voltijd Ad, zoals blijkt uit Figuur 17. Tussen 2012 en 2016 nam het percentage vrouwelijke afstudeerders daar namelijk toe van ongeveer 50\% tot 63\%, waarmee het in 2016 groter was dan dat van de voltijdse hbo-bachelor en mbo 4 bol. 
FIGUUR 16 Aandeel vrouwen in uitstroom naar opleiding (2012-2016)

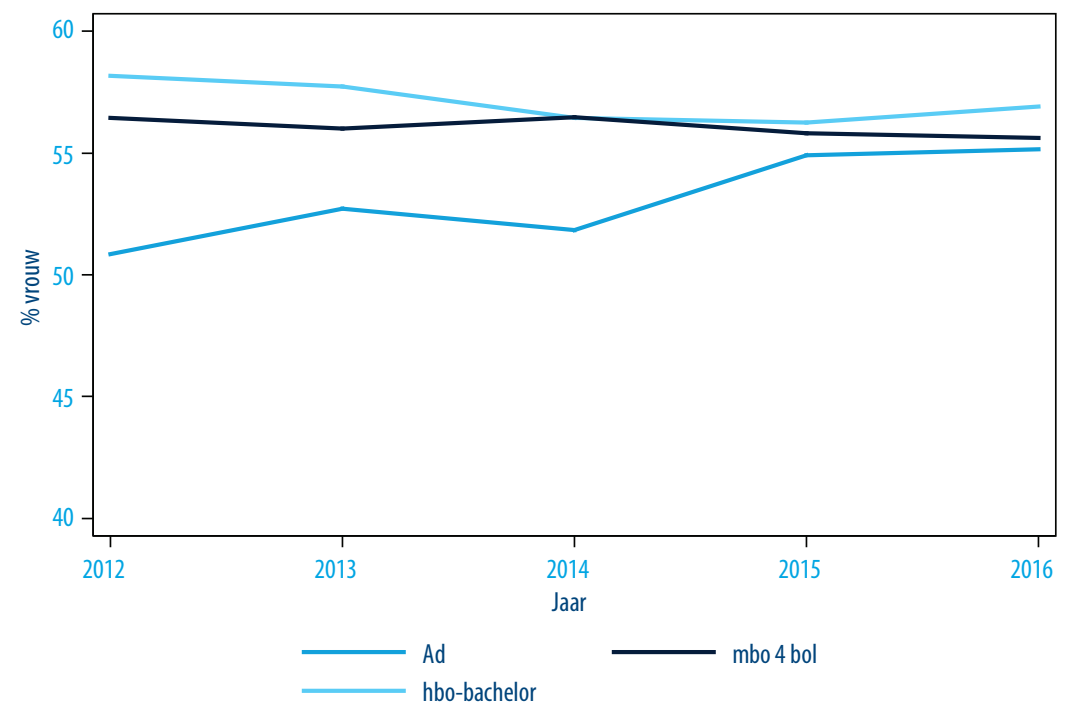

Bron: DUO/SSB

FIGUUR 17 Aandeel vrouwen in uitstroom naar opleiding, voltijd gediplomeerden (2012-2016)

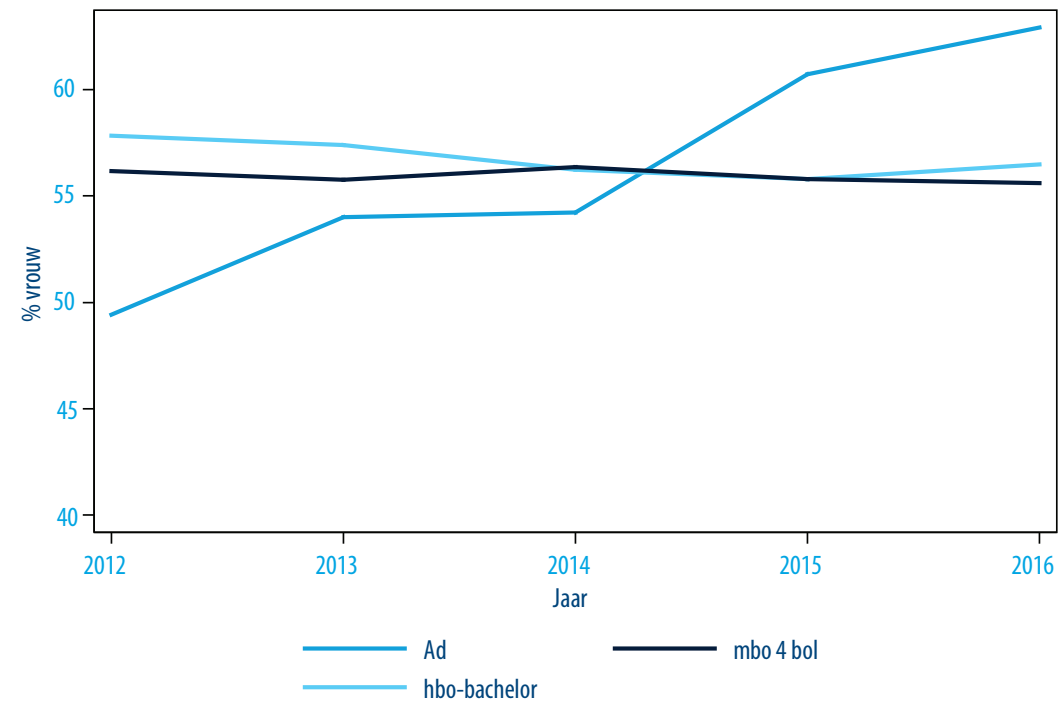

Bron: DUO/SSB

De leeftijdsverdeling van gediplomeerden naar opleidingsniveau in 2012 en 2016 wordt voorgesteld aan de hand van de zes boxplots in Figuur 18. Hieruit blijkt dat de mediane 
leeftijd van Ad-gediplomeerden in 2016 met 25 jaar hoger was dan die van mbo 4 bol-en hbo-bachelorgediplomeerden, waar de gemiddelde afstudeerleeftijd respectievelijk 20 en 24 jaar was. Verder is ook de leeftijdsspreiding van Ad'ers aanzienlijk groter dan van mbo 4 bol- en hbo-bachelorgediplomeerden. Beide vaststellingen zijn een gevolg van het feit dat een relatief grote groep Ad'ers bestaat uit personen die reeds actief zijn op de arbeidsmarkt en daardoor doorgaans wat ouder zijn. Opvallend is ook dat in 2012 de mediane leeftijd van Ad-gediplomeerden nog 27 jaar was, hetgeen wellicht een gevolg was van het destijds kleinere aandeel van Ad-voltijd-gediplomeerden (zie Figuur 10).

FIGUUR 18 Leeftijd gediplomeerden naar opleidingsniveau (2012 en 2016)

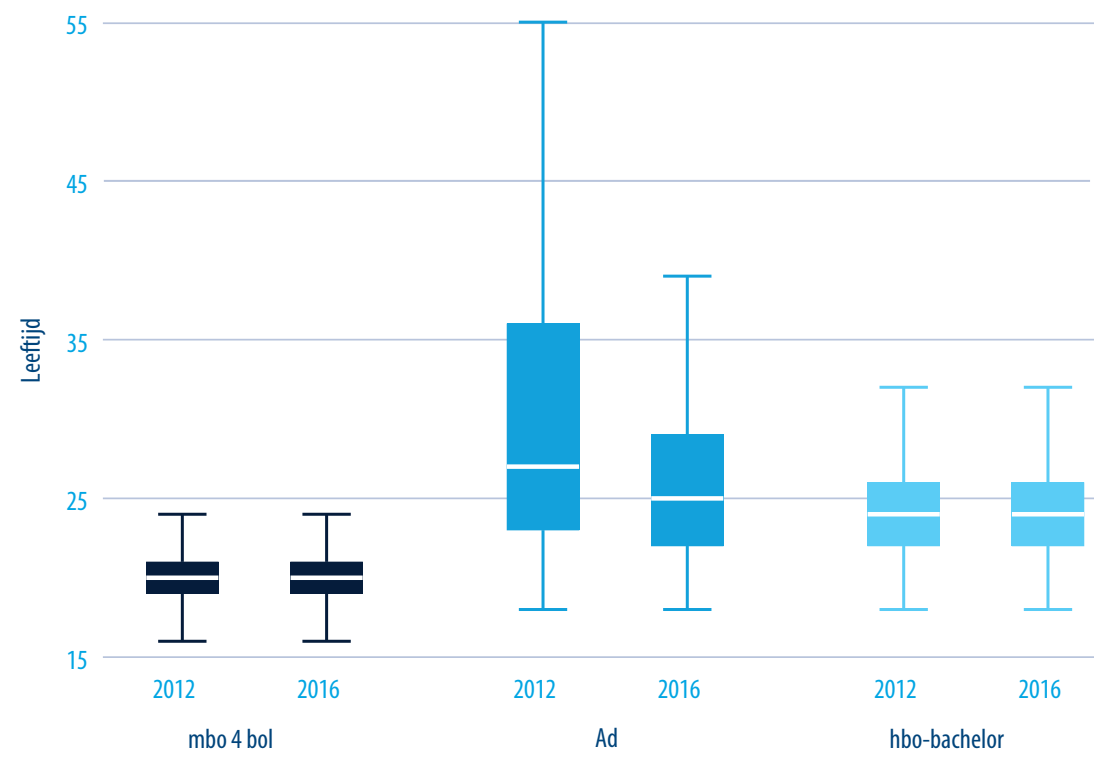

Bron: DUO/SSB

Dat de afwijkende leeftijdssamenstelling van Ad'ers hoofdzakelijk een gevolg is van oudere werknemers die een deeltijd of duaal opleidingstraject volgen blijkt uit Figuur 19, die uitsluitend kijkt naar de leeftijdsverdeling van gediplomeerden van voltijd programma's. Na gediplomeerden van deeltijd en duale opleidingen buiten beschouwing te laten, valt het leeftijdspatroon van Ad-opleidingen in 2016 terug tot een patroon dat vergelijkbaar is met dat van hbo-bachelor. De mediane leeftijd van voltijd Ad'ers is met 23 jaar dan namelijk even hoog als die van voltijd hbo-bachelorgediplomeerden. Hierbij dient echter opgemerkt te worden dat de normale studieduur van Ad en hbobachelor respectievelijk twee en vier jaar zijn, en voltijd Ad-studenten dus gemiddeld twee jaar ouder zijn wanneer ze hun opleiding aanvangen. 
FIGUUR 19 Leeftijd naar opleidingsniveau, voltijd gediplomeerden (2012 en 2016)

55

45

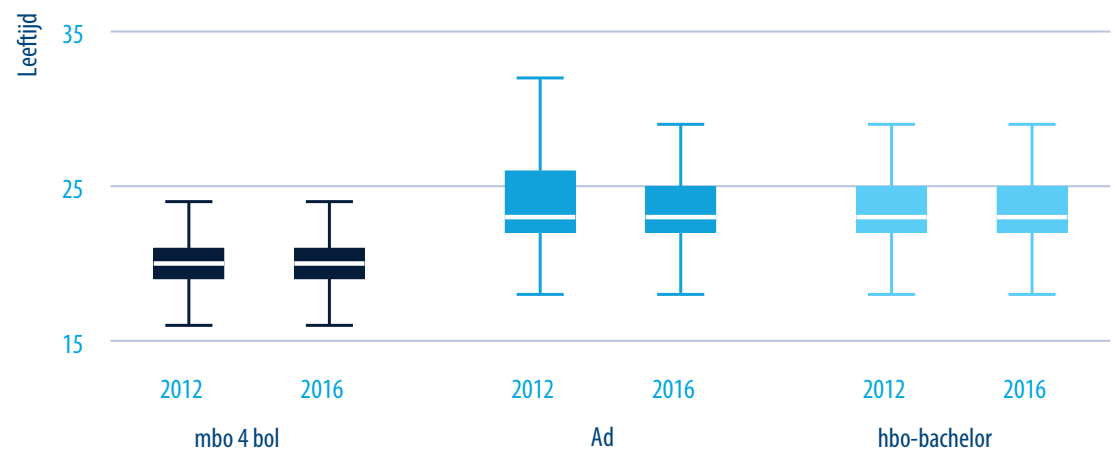

Bron: DUO/SSB 


\section{UITKOMSTEN VAN AD}

In dit hoofdstuk wordt gefocust op de uitkomsten van Ad-opleidingen en hoe deze zich verhouden tot de uitkomsten van mbo 4 bol- en hbo-bacheloropleidingen. Eerst gaan we in op een aantal subjectieve indicatoren met betrekking tot de tevredenheid met bepaalde aspecten van de opleiding. Vervolgens worden de resultaten met betrekking tot de arbeidsmarktuitkomsten en dus het rendement van Ad-opleidingen beschreven. Onder deze 'harde' indicatoren vallen de baankans, het loon, het aantal gewerkte uren, de kans op een vast contract, de kans op onderbenutting van vakkennis en de kans op werk op niveau en in het verlengde van de studierichting.

In het vorige hoofdstuk kwam naar voren dat Ad'ers gemiddeld ouder zijn en beduidend vaker werk en studie combineren dan mbo 4 bol- en hbo-bachelorgediplomeerden. Als gevolg hiervan wordt een belangrijk deel van de verschillen in de arbeidsmarktuitkomsten tussen deze groepen wellicht gedreven door verschillen in arbeidsmarktervaring. Beschrijvende statistieken die de arbeidsmarktpositie van afgestudeerde Ad'ers vergelijken met mbo 4 bol- en hbo-bachelorafgestudeerden zijn als gevolg van deze verschillen dus weinig informatief. Dit is de reden dat er in dit hoofdstuk uitsluitend gebruik zal worden gemaakt van regressieanalyse, waarin gecontroleerd kan worden voor onder andere verschillen in leeftijd en geslacht.

\subsection{Aanpak}

De uitkomsten zijn gebaseerd op gediplomeerden uit de jaren 2006-2007 tot 2016-2017, en worden, met uitzondering van de regressies voor het brutoloon en gewerkte uren, geschat met behulp van een probit model. Daarin wordt gecontroleerd voor leeftijd (lineair en kwadratisch), geslacht, migratieachtergrond, sector, jaar en (waar mogelijk) gemiddeld examencijfer. Door in de regressies te controleren voor leeftijd en de opleidingsniveaus te splitsen in voltijd, deeltijd en duaal wordt bovendien met arbeidsmarktervaring rekening gehouden. Telkens zal bij de regressieresultaten worden nagegaan hoe de uitkomsten van Ad-gediplomeerden zich verhouden tot die van mbo 4 bol- en hbo-gediplomeerden. Alle resultaten zijn in figuren gepresenteerd, waarbij het verschil in kans (marginale effecten) of het verschil in loon geïnterpreteerd moet worden ten opzichte van hbo-bachelorgediplomeerden uit voltijd opleidingen (de referentieca- 
tegorie). De uitkomsten kunnen strikt genomen niet causaal worden geïnterpreteerd omdat niet-waargenomen kenmerken een rol kunnen spelen in de keuze voor een Ad-opleiding en het rendement van de gevolgde opleiding.

Voor de regressies van de subjectieve indicatoren wordt gebruik gemaakt van data uit het SIS (BVE- en HBO-Monitor), en gaat het bijgevolg om schattingen die betrekking hebben op de periode anderhalf jaar na afstuderen. Een deel van de regressies voor de 'harde' indicatoren zijn daarentegen gebaseerd op administratieve data van GBA, DUO en het SSB, en handelen over de arbeidsmarktuitkomsten twee en vier jaar na afstuderen. Personen werden in deze data aangeduid als Ad-gediplomeerden indien zij na het afronden van de Ad geen vervolgdiploma hebben behaald. Een belangrijke kanttekening bij de regressies op vier jaar is ten slotte dat ze gebaseerd zijn op Ad'ers die afgestudeerd zijn in de periode 2006-2013. Omdat dit grotendeels de beginjaren van de Ad betreft, zou dit tot enige vertekening van de resultaten kunnen leiden. Bovendien zorgt de kortere periode voor een krimp van het aantal bruikbare observaties van ongeveer $30 \%$.

\subsection{Subjectieve indicatoren}

\section{Tevredenheidsoordelen achteraf}

Een eerste onderdeel van de uitkomsten van Ad-opleidingen zijn de oordelen van Ad-gediplomeerden over de gevolgde studie. Dit verdelen we verder onder in 1) de vraag of gediplomeerden achteraf gezien hun opleiding opnieuw zouden volgen, 2) de vraag of ze vinden dat hun opleiding hen een goede basis bood om te starten op de arbeidsmarkt, en 3) de vraag of ze vinden dat hun opleiding hen een goede basis bood voor hun verdere ontwikkeling. Omdat voor de tevredenheidsaspecten geen registerdata voor handen is, wordt voor deze drie deelcomponenten gebruik gemaakt van data uit het SIS (BVE- en HBO-Monitor). ${ }^{9}$ Teneinde de leesbaarheid van het rapport te vergroten worden de coëfficiënten van de probit regressies achterwege gelaten en worden rechtstreeks de marginale effecten van de voor dit rapport relevante variabele weergegeven (i.e. opleidingsniveau).

Het linkerpaneel van Figuur 20 bevat de resultaten voor de kans dat afgestudeerden achteraf gezien opnieuw voor dezelfde opleiding zouden kiezen. Daar het om marginale effecten gaat, zijn de oranje stippen te interpreteren als afwijkingen ten opzichte van de geschatte kans voor gediplomeerden van hbo-voltijd. Uit de figuur blijkt dat voltijd Ad-gediplomeerden op dit aspect niet significant afwijken van voltijd hbo-gediplomeerden op een significantieniveau van $5 \%$, en dus even geneigd zijn om hun opleiding opnieuw te volgen. Dat geldt echter niet voor gediplomeerden van een deeltijd of duale Ad-opleiding, die ongeveer 10 procentpunten meer geneigd zijn hun opleiding

9 Het gebruik van BVE- en HBO-Monitor-data maakt dat ook voor het gemiddelde examencijfer van gediplomeerden gecontroleerd kon worden. 
opnieuw te volgen dan gediplomeerden van hbo-voltijd. Verder valt op dat ook gediplomeerden van mbo 4 bol even hoog scoren als voltijd hbo-gediplomeerden.

FIGUUR 20 Resultaten voor tevredenheidsoordelen achteraf (anderhalf jaar na afstuderen, BVEen HBO-Monitor-data) ${ }^{10}$

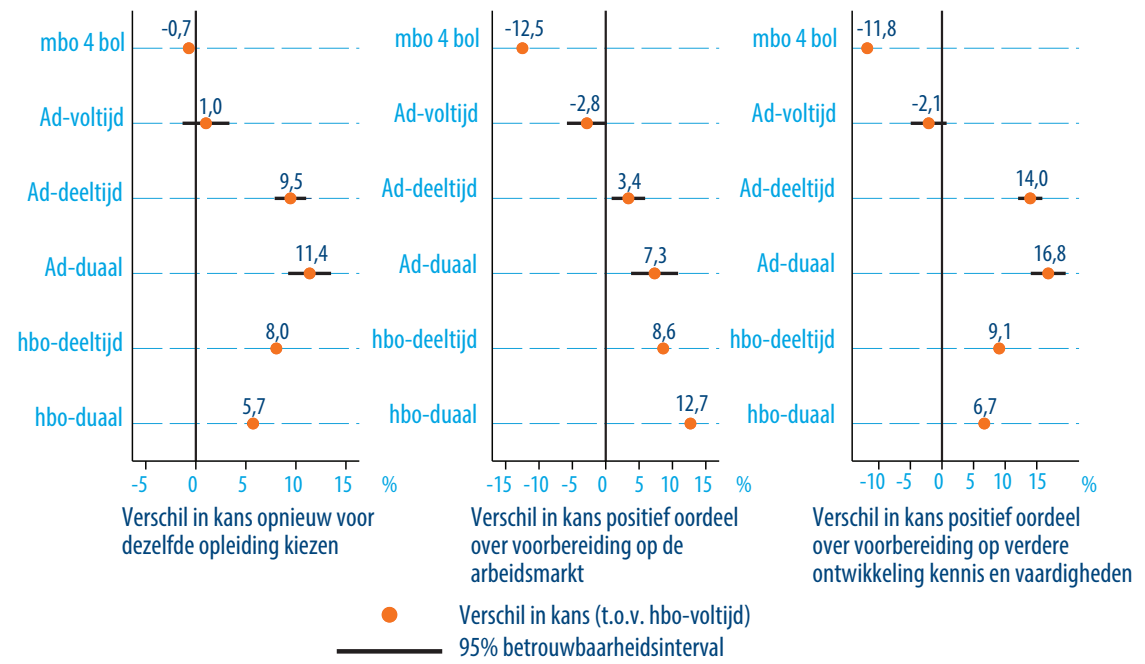

Model: probit regressies gecontroleerd voor leeftijd (lineair en kwadratisch), geslacht, migratieachtergrond, jaar, sector en examencijfer

Bron: BVE-Monitor, HBO-Monitor

Een tweede tevredenheidsaspect is de vraag in hoeverre de opleiding volgens gediplomeerden een goede basis bood voor de intrede op de arbeidsmarkt. Het middelste paneel van Figuur 20 geeft aan dat ook voor deze component de kans voor Ad-voltijd niet statistisch significant afwijkt van hbo-voltijd. Afgestudeerden van Ad-duaal hebben daarentegen een kans om positief te oordelen over de mate waarin de opleiding een goede basis bood voor de arbeidsmarktintrede die 7 procentpunten hoger ligt dan de kans voor gediplomeerden van hbo-voltijd. Het omgekeerde geldt voor de geschatte kans van mbo 4 bol, die 12 procentpunten lager ligt dan die van hbo-voltijd.

Het rechterpaneel van Figuur 20 toont ten slotte de resultaten voor de kans dat gediplomeerden positief oordelen over de mate waarin hun opleiding hen in staat stelde om hun kennis en vaardigheden verder te ontwikkelen. Ook hier verschillen Ad-voltijd en hbo-voltijd niet significant van elkaar. Dat is wel het geval voor mbo 4 bol, waarvoor de geschatte kans gemiddeld 12 procentpunten kleiner is dan die van hbo-voltijd. De kans

10 In tegenstelling tot in de administratieve data kan in de BVE- en HBO-Monitor-data bij mbo 4 bol geen betrouwbaar onderscheid gemaakt worden tussen voltijd en deeltijd omdat het aantal respondenten uit mbo 4 bol-deeltijd te klein is. 
dat Ad-deeltijd en Ad-duaal positief oordelen is daarentegen respectievelijk gemiddeld 14 en 17 procentpunten hoger.

Samenvattend kan gesteld worden dat gediplomeerden van Ad-voltijd na controle voor achtergrondkenmerken qua oordelen over hun opleiding niet significant afwijken van gediplomeerden van hbo-voltijd. Gediplomeerden van Ad-deeltijd en Ad-duaal zijn daarentegen meestal wel meer tevreden over hun studie dan voltijd Ad- en voltijd hbogediplomeerden. Het oordeel van mbo 4 bol-gediplomeerden is ten slotte voor alle onderzochte tevredenheidsaspecten negatiever dan voor gediplomeerden van $\mathrm{Ad}$ - en hbo-voltijd.

\subsection{Objectieve indicatoren}

In deze paragraaf gaan we in op een reeks objectieve indicatoren van het rendement van opleidingen, meer bepaald 1) de kans op werkloosheid, 2) de baankans, 3) de kans om werkt te hebben op niveau en in het verlengde van de studierichting, 4) de kans op onderbenutting van vakkennis, 5) het bruto-uurloon, 6) het aantal gewerkte uren en 7) de kans op een vaste aanstelling. In tegenstelling tot bij de subjectieve indicatoren, zijn een deel van de analyses in deze paragraaf gebaseerd op administratieve data. Die bieden de mogelijkheid om een langere tijdshorizon te hanteren bij de bepaling van het rendement, zodat de verschillen zowel twee als vier jaar na diplomering geanalyseerd kunnen worden.

\section{Werkloosheid}

Een eerste indicator voor het rendement van Ad-opleidingen betreft de kans op werkloosheid. Hiervoor wordt gebruik gemaakt van gegevens uit de BVE- en HBO-Monitor voor de periode 2006-2016. De keuze voor BVE- en HBO-Monitor-data is een gevolg van het feit dat de werkloze beroepsbevolking, zijnde het aandeel van de beroepsbevolking dat geen baan heeft maar daar wel actief naar zoekt, niet kan geïdentificeerd worden in de administratieve data.

Figuur 21 geeft de resultaten weer voor de kans om anderhalf jaar na afstuderen werkloos te zijn. De kans op werkloosheid verschilt niet significant tussen gediplomeerden van Ad-voltijd en hbo-voltijd. Dit is echter wel het geval voor Ad-deeltijd en Ad-duaal in vergelijking met hbo-voltijd. Afgestudeerden van deze opleidingen hebben namelijk een kans op werkloosheid die bijna 5 procentpunten lager ligt dan voltijd hbo-gediplomeerden. Dit is niet verrassend gezien veel van de personen in deeltijd en duale programma's werk en studie combineren. Gediplomeerden van mbo 4 bol hebben daarentegen een kans op werkloosheid die 1,4 procentpunten hoger ligt dan afgestudeerden van hbo-voltijd. 
FIGUUR 21 Resultaten voor de kans op werkloosheid (anderhalf jaar na afstuderen)

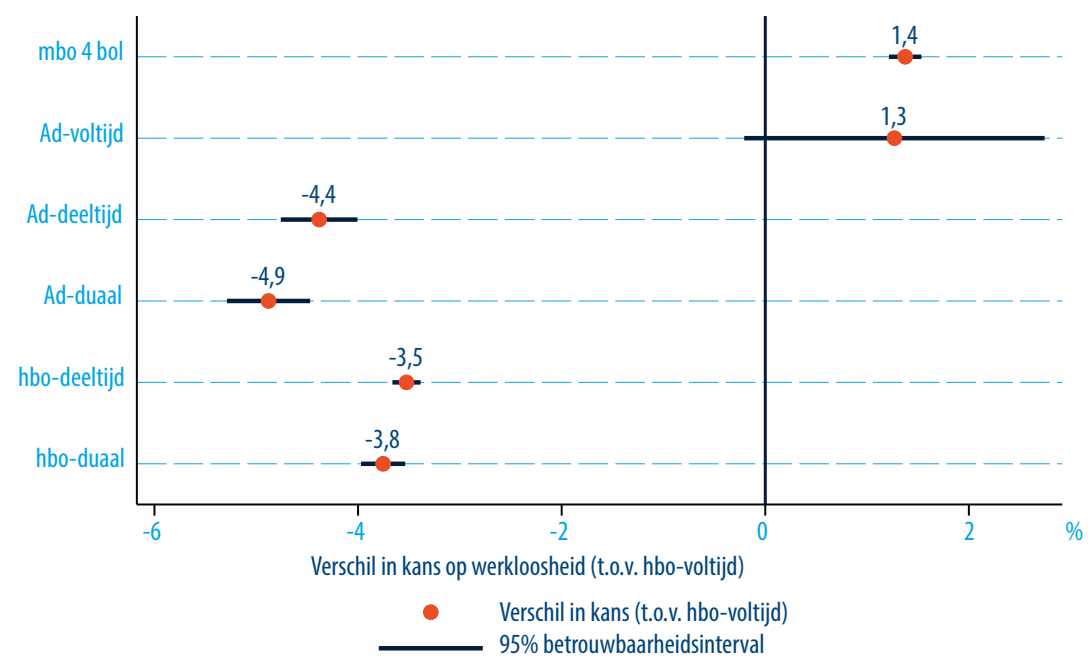

Model: probit regressie gecontroleerd voor leeftijd (lineair en kwadratisch), geslacht, migratieachtergrond, jaar, sector en examencijfer

Bron: BVE-Monitor, HBO-Monitor

\section{Baankans}

Een tweede indicator voor het rendement van Ad-opleidingen is de kans op het al dan niet hebben van werk, ofwel de baankans. In tegenstelling tot de werkloze beroepsbevolking, kan het al dan niet werkzaam zijn van iemand wel worden vastgesteld in de administratieve data.

De schattingsresultaten voor de kans om twee jaar na afstuderen een baan te hebben worden gepresenteerd in het linkerpaneel van Figuur 22. Daaruit blijkt dat gediplomeerden van Ad-voltijd na twee jaar een baankans hebben die bijna 2 procentpunten kleiner is dan de kans voor gediplomeerden van hbo-voltijd. Ad-deeltijd en Ad-duaal kennen daarentegen een baankans die ongeveer 10 procentpunten groter is dan de kans voor hbo-voltijd, hetgeen wellicht gedreven wordt door het feit dat een aanzienlijk deel van hen reeds een baan heeft tijdens de studie (zie Figuur 7 en Figuur 8). Afgestudeerden van mbo 4 bol (voltijd) hebben ten slotte een kans die ongeveer 16 procentpunten kleiner is dan voor hbo-voltijd om twee jaar na afstuderen werkzaam te zijn. 
FIGUUR 22 Resultaten voor baankans (twee en vier jaar na afstuderen)

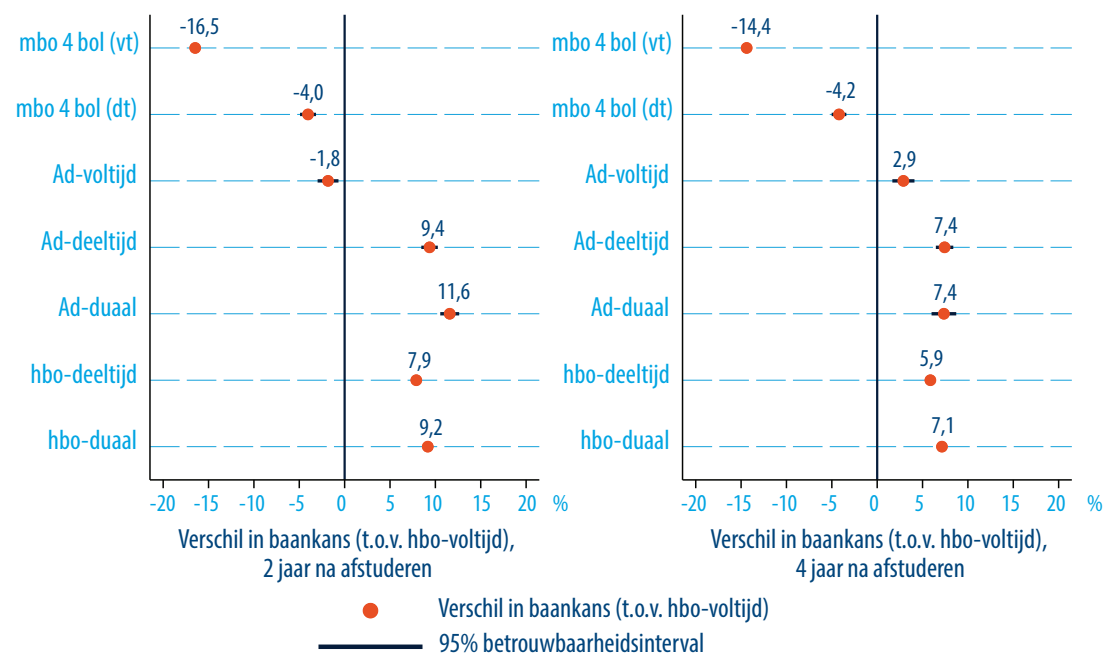

Model: probit regressie gecontroleerd voor leeftijd (lineair en kwadratisch), geslacht, migratieachtergrond, sector en jaar

Bron: DUO/SSB

De resultaten voor de kans om vier jaar na afstuderen een baan te hebben worden voorgesteld in het rechterpaneel van Figuur 22, en verschillen niet wezenlijk van de cijfers na twee jaar. De kans op een baan voor gediplomeerden van Ad-voltijd is na vier jaar wel iets groter dan voor hbo-voltijd. Voor Ad-deeltijd en Ad-duaal verkleint de positieve kloof met hbo-voltijd, maar blijft nog ongeveer 7 procentpunten. Opnieuw is ook de kans op werk aanzienlijk kleiner voor mbo 4 bol (voltijd).

\section{Baan op niveau en in verlengde van studierichting}

Dat de baankansen voor Ad-voltijd en hbo-voltijd vrij sterk overeenkomen hoeft echter niet te betekenen dat Ad-gediplomeerden ook evenveel kans hebben op een baan die zich op hetzelfde niveau en in dezelfde sector als hun gevolgde opleiding bevindt. Deze paragraaf gaat hier dieper op in. Omdat hiervoor geen administratieve data voor handen is, wordt informatie uit de BVE- en HBO-Monitor gebruikt."

Uit het linkerpaneel van Figuur 23 blijkt dat Ad-gediplomeerden, ongeacht de opleidingsvorm, een aanzienlijk grotere kans hebben om onder hun niveau te werken dan gediplomeerden van hbo-voltijd. Voor afgestudeerden van Ad-voltijd ligt de geschatte kans namelijk gemiddeld 15 procentpunten hoger dan voor afgestudeerden van hbovoltijd. Voor Ad-deeltijd en Ad-duaal is de kans om onder het opleidingsniveau werkzaam te zijn met respectievelijk 22 procentpunten en 17 procentpunten meer dan hbo-

11 Wegens een gebrek aan data zijn de resultaten met betrekking tot de kans om te werken onder het opleidingsniveau gebaseerd op de periode 2013-2016. 
voltijd. Een voor de hand liggende verklaring voor de grotere kans op onderbenutting bij Ad-deeltijd en Ad-duaal is dat de personen in deze opleidingsvormen vaak reeds werkzaam zijn op mbo 4-niveau of lager, en wellicht na afstuderen niet altijd opklimmen naar een functie op Ad-niveau. Een mbo 4 bol-opleiding geeft ten slotte een iets kleinere kans op onderbenutting dan een voltijd hbo-bacheloropleiding.

Het rechterpaneel van Figuur 23 behandelt de kans op werk buiten de opleidingsrichting anderhalf jaar na afstuderen. Gediplomeerden van Ad-voltijd hebben gemiddeld bijna 4 procentpunten meer kans om buiten hun richting werkzaam te zijn dan afgestudeerden van hbo-voltijd. De kans voor mbo 4 bol-gediplomeerden is zelfs 9 procentpunten groter.

FIGUUR 23 Resultaten voor de arbeidsmarktpositie (anderhalf jaar na afstuderen)
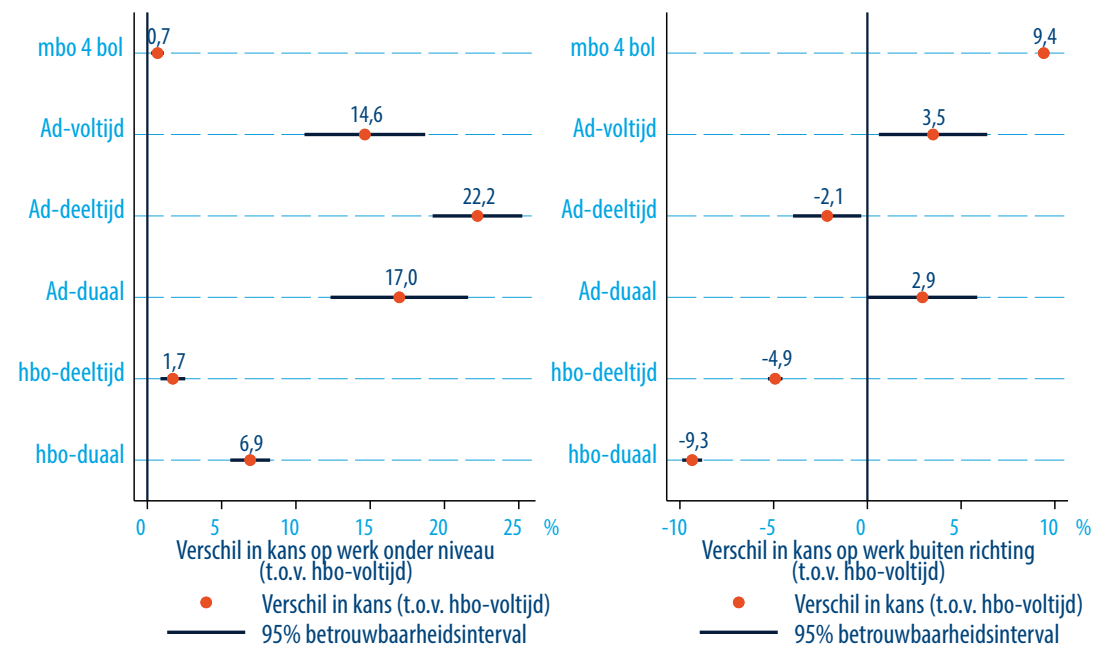

Model: probit regressie gecontroleerd voor leeftijd (lineair en kwadratisch), geslacht, migratieachtergrond, jaar, sector en examencijfer

Bron: BVE-Monitor, HBO-Monitor

\section{Onderbenutting vakkennis}

Naast een mismatch qua niveau en richting kan er eveneens een mismatch zijn wat betreft kennisbenutting. Figuur 24 toont de resultaten voor de kans om anderhalf jaar na afstuderen een baan te hebben waarvoor afgestudeerden aangeven dat hun eigen niveau van vakkennis lager is dan het vereiste kennisniveau. ${ }^{12}$ Een positieve waarde staat voor een grotere kans op onderbenutting van de kennis van het eigen vakgebied in vergelijking met hbo-bachelor voltijd.

$\overline{12}$ Wegens een gebre $\mathrm{k}$ aan data zijn geen analyses beschikbaar voor mbo-gediplomeerden. 
De kans dat gediplomeerden van Ad-voltijd anderhalf jaar na afstuderen een baan hebben die minder eigen vakkennis vereist dan ze bezitten, verschilt niet significant van de kans voor gediplomeerden van hbo-voltijd. Afgestudeerden van Ad-deeltijd en Ad-duaal hebben daarentegen respectievelijk 8 en 5 procentpunten meer kans op werk waar eigenlijk minder eigen vakkennis voor nodig is dan ze hebben. Dit zou verklaard kunnen worden doordat het vaak om werkende schoolverlaters gaat die mogelijk na diplomering niet doorgroeien naar een baan of takenpakket op hoger niveau.

FIGUUR 24 Resultaten voor onderbenutting kennis eigen vakgebied (anderhalf jaar na afstuderen)

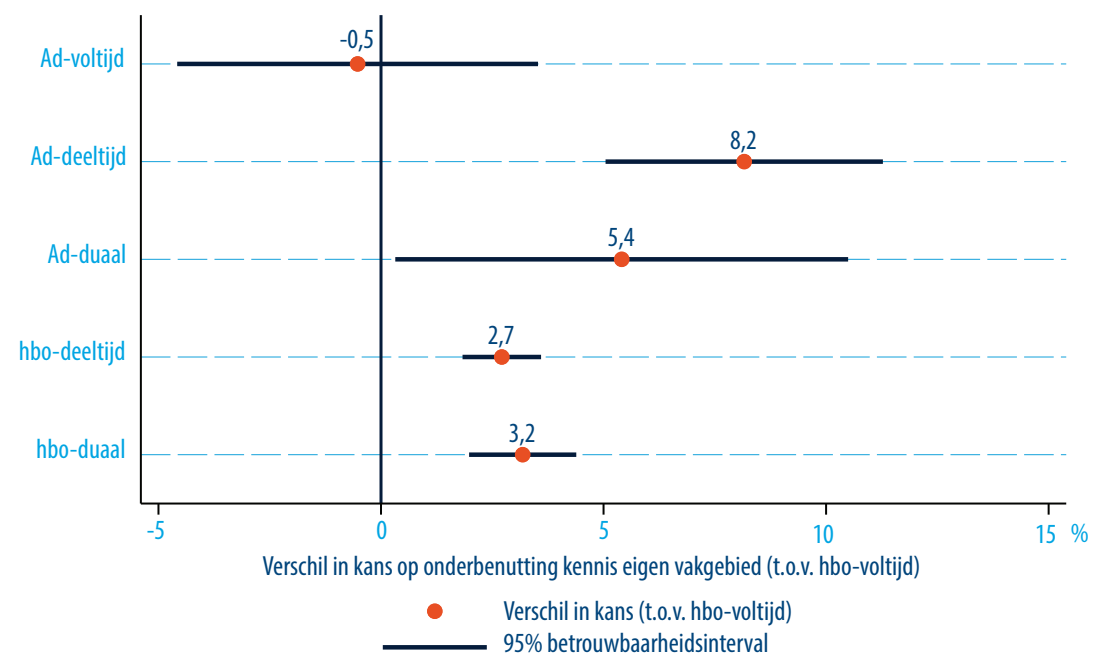

Model: probit regressie gecontroleerd voor leeftijd (lineair en kwadratisch), geslacht, migratieachtergrond, sector, jaar en examencijfer

Bron: HBO-Monitor

\section{Uurloon}

Een gebruikelijke methode om het rendement van opleidingen te beoordelen is om uurloonverschillen te analyseren. Een moeilijkheid bij de kwantificering van het effect van de gevolgde opleiding op het loon is echter dat de loonverdeling gekarakteriseerd wordt door grote uitschieters, die derhalve de schattingen kunnen vertekenen. Dit is de reden dat er voor wordt gekozen om de loonschattingen uit te voeren door middel van een kwantielregressie. In plaats van een schatting op te leveren van het gemiddelde effect van de onafhankelijke variabelen op het conditionele gemiddelde van de afhankelijke variabele (i.e. het loon), zoals het geval is bij de kleinste kwadratenmethode, kan een kwantielregressie het effect op de verschillende kwantielen van de verdeling van de afhankelijke variabele berekenen. ${ }^{13}$ Niettegenstaande de volledige loondistributie in

13 Voor een verdere toelichting, zie Koenker, R., \& Bassett, G. (1978). Regression quantiles. Econometrica, 46, 33-50. 
principe op deze wijze geanalyseerd kan worden, gaat de voorkeur in dit rapport uit naar het effect op een individu in het midden van de distributie, ofwel de mediaan van de loonverdeling.

Het linkerpaneel van Figuur 25 toont de schattingsresultaten voor het mediane brutouurloon twee jaar na afstuderen. Wat opvalt is dat het loonrendement van Ad-voltijd een positie inneemt tussen mbo 4 bol (voltijd) en hbo-voltijd. Gediplomeerden van Ad-voltijd verdienen twee jaar na diplomering gemiddeld namelijk bijna 11\% minder per uur dan gediplomeerden van hbo-voltijd, en gediplomeerden van mbo 4 bol (voltijd) ongeveer $23 \%$ minder. Afgestudeerden van Ad-deeltijd en Ad-duaal verdienen daarentegen gemiddeld bijna 10\% meer, wat wellicht een gevolg is van hun grotere anciënniteit en arbeidsmarktervaring.

FIGUUR 25 Resultaten voor het mediane bruto-uurloon (twee en vier jaar na afstuderen)

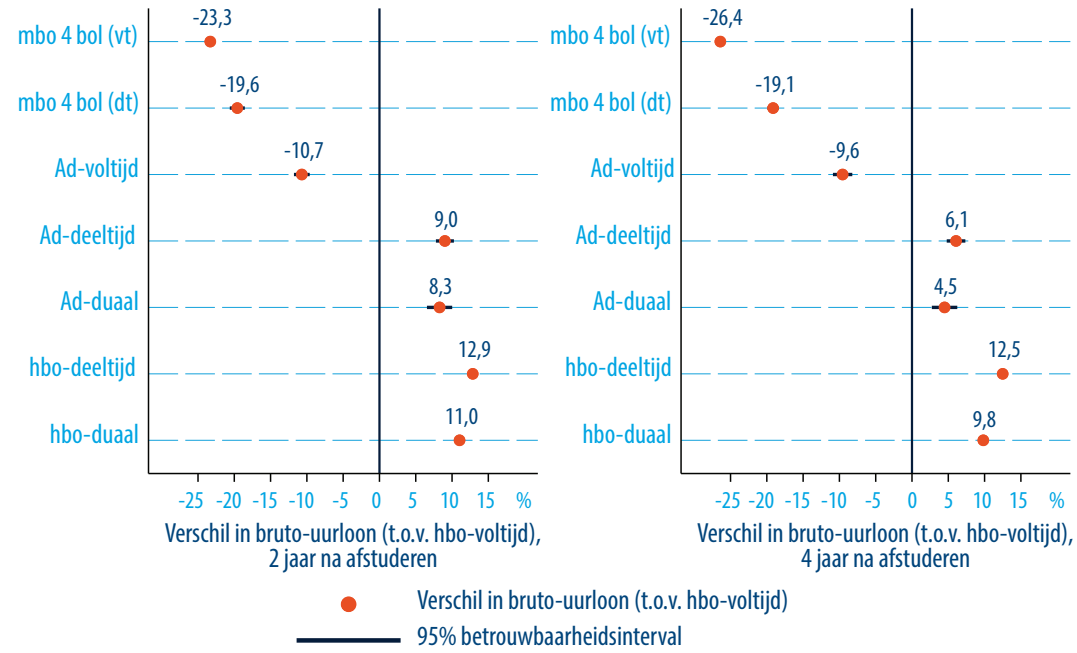

Model: kwantielregressie gecontroleerd voor leeftijd (lineair en kwadratisch), geslacht, migratieachtergrond, sector en jaar

Bron: DUO/SSB

De tussenpositie van het loonrendement van Ad-voltijd is vier jaar na afstuderen nog steeds zichtbaar, zoals blijkt uit de resultaten aan de rechterkant van Figuur 25. Gediplomeerden van Ad-voltijd verdienen vier jaar na diplomering gemiddeld nog steeds ongeveer $10 \%$ minder per uur dan gediplomeerden van hbo-voltijd. Wel is de positieve kloof tussen Ad-deeltijd/duaal en hbo-voltijd na vier jaar teruggelopen tot ongeveer $5 \%$. 
In de bijlage zijn eveneens de schattingsresultaten opgenomen voor het bruto-jaarloon (zie Figuur 29). Daaruit valt op te maken dat ook op jaarbasis het mediane financiële rendement van Ad'ers meer dan 10\% lager ligt dan dat van hbo-voltijd. Net zoals bij het bruto-uurloon is deze kloof na vier jaar nog steeds zichtbaar. Gediplomeerden van mbo 4 bol (voltijd) hebben een mediaan jaarsalaris dat meer dan $50 \%$ kleiner is dan dat van gediplomeerden van hbo-voltijd. Dit rendementsverschil is aanzienlijk groter dan bij het bruto-uurloon, wat een gevolg is van de kortere wekelijkse arbeidsduur (zie volgende paragraaf).

\section{Gewerkte uren}

Een derde component van het relatieve rendement van Ad-opleidingen is het aantal gewerkte uren. De keuze om de arbeidsduur te classificeren als onderdeel van het rendement behoeft echter enige nuance. Hoewel de arbeidsduur sterk bepalend is voor het maandinkomen, is het aantal gewerkte uren in veel gevallen een bewuste keuze. In de onderwijs- en zorgsector is het bijvoorbeeld gebruikelijk dat werkenden, veelal vrouwen, ervoor kiezen om de zorg voor hun kinderen te combineren met een verminderde arbeidsduur. Wellicht hadden deze personen echter vaak wel de mogelijkheid om meer uren te werken. In dat geval zou het foutief zijn om het kleinere urenaantal te beschouwen als een lager rendement. Dit is een kanttekening die in het achterhoofd dient gehouden te worden bij de interpretatie van de resultaten.

FIGUUR 26 Resultaten voor het aantal gewerkte uren per week (twee en vier jaar na afstuderen)

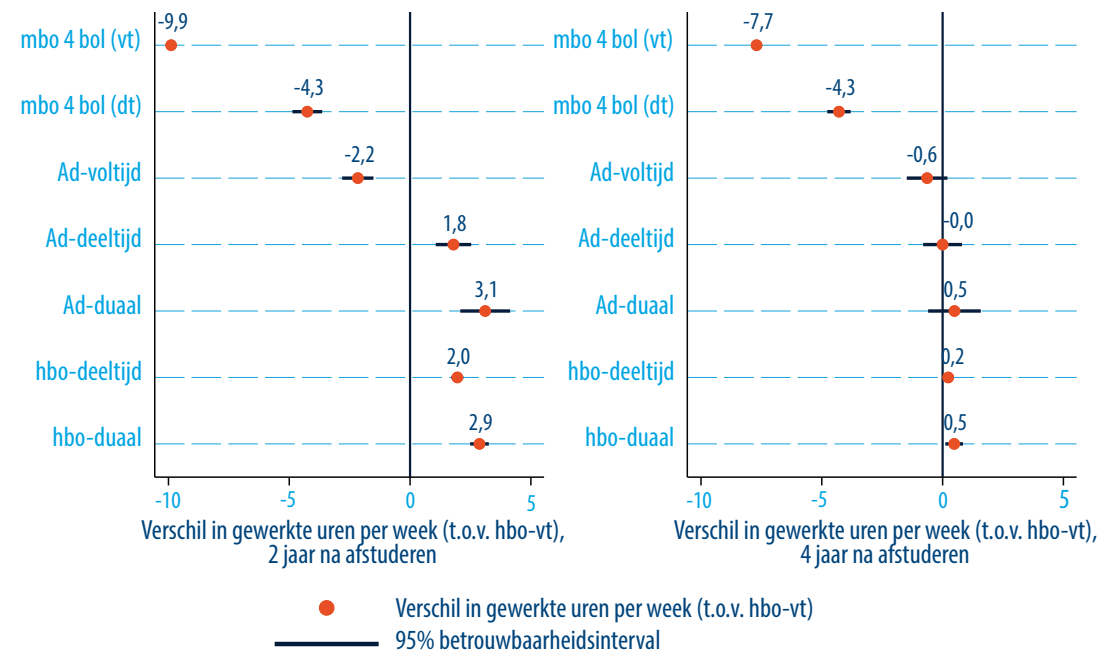

Model: kwantielregressie gecontroleerd voor leeftijd (lineair en kwadratisch), geslacht, migratieachtergrond, sector en jaar Bron: DUO/SSB 
Het linkerpaneel van Figuur 26 geeft de schattingsresultaten weer voor het verschil in wekelijkse arbeidsduur tussen hbo-voltijd en de andere opleidingsniveaus twee jaar na afstuderen. ${ }^{14}$ Gediplomeerden van Ad-voltijd werken gemiddeld 2 uur per week minder dan gediplomeerden van hbo-voltijd, terwijl afgestudeerden van Ad-deeltijd en Ad-duaal gemiddeld respectievelijk 2 en 3 uur per week meer werken dan hbo-voltijd. Afgestudeerden van mbo 4 bol (voltijd) werken daarentegen bijna 10 uur per week minder.

Vier jaar na afstuderen is het verschil in wekelijkse arbeidsduur tussen Ad-voltijd en hbovoltijd niet meer significant, zoals de rechterzijde van Figuur 26 laat zien. Gediplomeerden van Ad-deeltijd en Ad-duaal werken na vier jaar ook niet meer dan gediplomeerden van hbo-voltijd. Afgestudeerden van mbo 4 bol werken echter nog steeds gemiddeld 8 uur per week minder.

\section{Type contract}

Ten slotte kan het rendement van Ad-opleidingen eveneens benaderd worden vanuit de kans op een vaste aanstelling. Zoals blijkt uit het linkerpaneel van Figuur 27, maken gediplomeerden van Ad-voltijd anderhalf jaar na afstuderen niet meer of minder kans op een vast contract dan gediplomeerden van hbo-voltijd. Afgestudeerden van Ad-deeltijd en Ad-duaal hebben daarentegen anderhalf jaar na diplomering bijna 35 procentpunten meer kans op een vaste aanstelling dan hbo-voltijd. Dit grote verschil is waarschijnlijk een gevolg van hun grotere arbeidsmarktervaring, en het feit dat een deel van hen wellicht reeds een vaste aanstelling had voordat ze aan hun Ad-opleidingen begonnen.

FIGUUR 27 Resultaten voor de kans op een vaste aanstelling (anderhalf jaar na afstuderen)

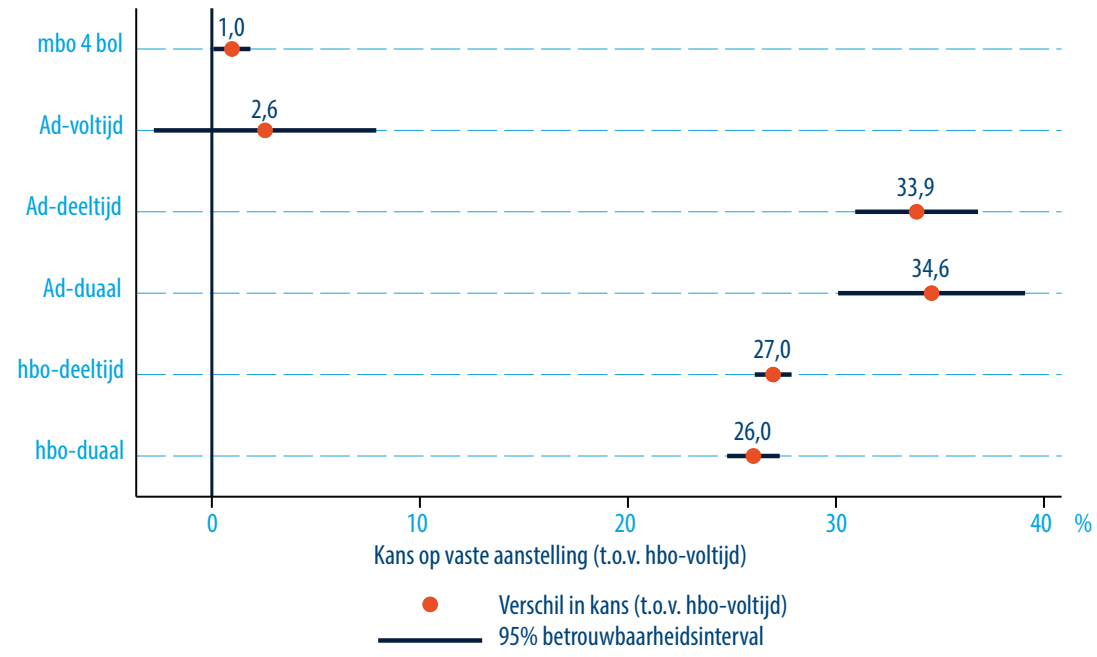

Model: probit regressie gecontroleerd voor leeftijd (lineair en kwadratisch), geslacht, migratieachtergrond, jaar, sector en examencijfer

Bron: BVE-Monitor, HBO-Monitor

14 Gezien de administratieve data enkel het aantal gewerkte uren per jaar bevat, werd het aantal wekelijkse arbeidsuren berekend door het jaarcijfer te delen door 52 . 



\section{RELEVANTIE VAN DE HBO-MONITOR- DATA}

Het voordeel van het gebruik van administratieve data is dat het bijna alle gediplomeerden en ingeschrevenen meeneemt, waardoor schattingen minder snel vertekend worden als gevolg van datagerelateerde redenen. ${ }^{15}$ Een nadeel is echter dat slechts een beperkte set aan variabelen op die manier is geregistreerd. In het vorige hoofdstuk werd daarom voor de analyses waarvoor geen administratieve data van DUO en het SSB voor handen was gebruik gemaakt van HBO-Monitor-data. Er valt bijvoorbeeld met administratieve data niet of slechts gedeeltelijk vast te stellen of werkenden onder hun opleidingsniveau of buiten hun opleidingssector werkzaam zijn, en of ze een baan hebben waarin ze hun competenties ten volle kunnen benutten. Subjectieve indicatoren met betrekking tot bepaalde opleidingsaspecten zijn er eveneens niet in opgenomen.

Het omgekeerde is echter vaak wel mogelijk. Een aanzienlijk deel van de Ad-analyses die in dit rapport met administratieve data zijn uitgevoerd, zijn ook uitvoerbaar met de HBO-Monitor. Dit biedt de mogelijkheid om na te gaan in hoeverre de resultaten met HBO-Monitor-data afwijken van de resultaten voor Ad-gediplomeerden met administratieve data. Hierbij kijken we zowel naar beschrijvende cijfers als naar regressieresultaten. Deze oefening geeft een indicatie van de kwaliteit en gebruikswaarde van de Ad-data in de HBO-Monitor, en kan gebruikt worden om een breder gebruik van data uit de HBO-Monitor over Ad-gediplomeerden te stimuleren, en om de bevraging van Ad-gediplomeerden in de HBO-Monitor te optimaliseren. Bij de vergelijking van de cijfers dient wel in het achterhoofd te worden gehouden dat de HBO-Monitor-data voor Ad'ers momenteel nog ongewogen is, waardoor een zekere afwijking ten opzichte van populatiedata bij voorbaat te verwachten is. De uitkomst van de hier beschreven resultaten kunnen eventueel als eerste stap naar een weging van Ad-cijfers in de HBO-Monitor dienen.

Tabel 1 toont per Ad-type het percentage vrouwen en de mediane leeftijd in de administratieve DUO/SSB-data en de HBO-Monitor-data. Het betreft daarbij cijfers voor gediplomeerden. Voor afgestudeerden van Ad-voltijd en Ad-duaal lijken zowel het percentage vrouwen als de mediane leeftijd uit de administratieve data sterk op de cijfers uit de HBO-Monitor-data. Voor Ad-deeltijd is het verschil echter groter. Voor

15 Zoals eerder aangegeven zijn gediplomeerden van de Open Universiteit en van particuliere (niet-bekostigde) hogere onderwijsinstellingen niet in de administratieve data opgenomen. 
afgestudeerden geeft de HBO-Monitor zowel voor het percentage vrouwen als de mediane leeftijd een lichte overschatting. Het lijkt er dus op dat de vertekening van de Ad-data in de HBO-Monitor op dit moment het grootst is voor Ad-deeltijd. Deze vertekening zou wellicht kunnen worden rechtgezet door een weegfactor te creëren voor de Ad-gediplomeerden in de HBO-Monitor.

Tabel 2 geeft het aandeel Ad-gediplomeerden naar leeftijdsklasse weer in zowel de HBO-Monitor-data als de administratieve data. Vanwege onthullingsgevaar zijn de administratieve cijfers voor Ad-voltijd niet weergegeven. Uit de boxplot in Figuur 19 valt echter op te maken dat de leeftijdscijfers voor Ad-voltijd sterk lijken op die uit de HBO-Monitor. De leeftijdsverdeling binnen Ad-duaal maar met name Ad-deeltijd is daarentegen wat minder representatief; ouderen zijn in beide opleidingstypes enigszins oververtegenwoordigd. Ook hier kan een weegfactor voor de Ad'ers een oplossing bieden. Daarnaast kan getracht worden om jongere deeltijd en duale Ad-gediplomeerden extra aan te sporen deel te nemen aan de HBO-Monitor.

TABEL 1 Geslacht en mediane leeftijd in gediplomeerdendata DUO/SSB en de HBO-Monitor (2016-2017)

\begin{tabular}{|l|c|c|c|c|c|c|c|}
\hline & \multicolumn{2}{|c|}{ Ad-voltijd } & \multicolumn{2}{c|}{ Ad-deeltijd } & \multicolumn{3}{c|}{ Ad-duaal } \\
\hline & DU0/SSB & HBO-Monitor & DUO/SSB & HBO-Monitor & DU0/SSB & HBO-Monitor \\
\hline Vrouw (\%) & 62,9 & 60,8 & 46,9 & 54,8 & 41,4 & 37,0 \\
\hline Leeftijd (mediaan) & 23 & 24 & 30 & 34 & 28 & 28 \\
\hline
\end{tabular}

Bron: DUO/SSB en HBO-Monitor

TABEL 2 Leeftijdsverdeling gediplomeerdendata in DUO/SSB en de HBO-Monitor (2016-2017)

\begin{tabular}{|l|r|c|c|c|c|c|}
\hline & \multicolumn{2}{|c|}{ Ad-voltijd } & \multicolumn{2}{c|}{ Ad-deeltijd } & \multicolumn{3}{c|}{ Ad-duaal } \\
& DU0/SSB & HBO-Monitor & DU0/SSB & HBO-Monitor & DU0/SSB & HB0-Monitor \\
\hline Aandeel <30 & $/$ & 96,0 & 49,6 & 31,1 & 68,6 & 60,5 \\
\hline Aandeel 30-39 & $/$ & 2,4 & 28,0 & 28,2 & 19,0 & 23,7 \\
\hline Aandeel 40-49 & $/$ & 0,8 & 16,5 & 26,7 & 9,5 & 13,2 \\
\hline Aandeel 50+ & $/$ & 0,8 & 5,9 & 14,1 & 3,0 & 2,6 \\
\hline
\end{tabular}

Bron: DUO/SSB en HBO-Monitor

Naast een vergelijking van beschrijvende statistieken, kan ook gekeken worden naar de mate waarin de regressieresultaten voor Ad-gediplomeerden verschillen bij het gebruik van administratieve data en HBO-Monitor-data. In een aanvullende analyse maken we deze vergelijking ook voor het bruto-uurloon.

Zoals blijkt uit Figuur 28 lijken de Ad-schattingen voor het bruto-uurloon op basis van de HBO-Monitor-data zeer sterk op de resultaten die gebaseerd zijn op de administratieve data. Deze gelijkenis kan gezien worden als een validering van de kwaliteit van de HBO-Monitor-data. Te meer omdat de loonresultaten voor hbo-deeltijd, hbo-duaal en mbo 4 bol (niet getoond) eveneens niet wezenlijk anders zijn bij het gebruik van de BVE- en HBO-Monitor-data. 
FIGUUR 28 Vergelijking regressiecoëfficiënten op basis van administratieve data en HBO-Monitor- data voor bruto-uurloon

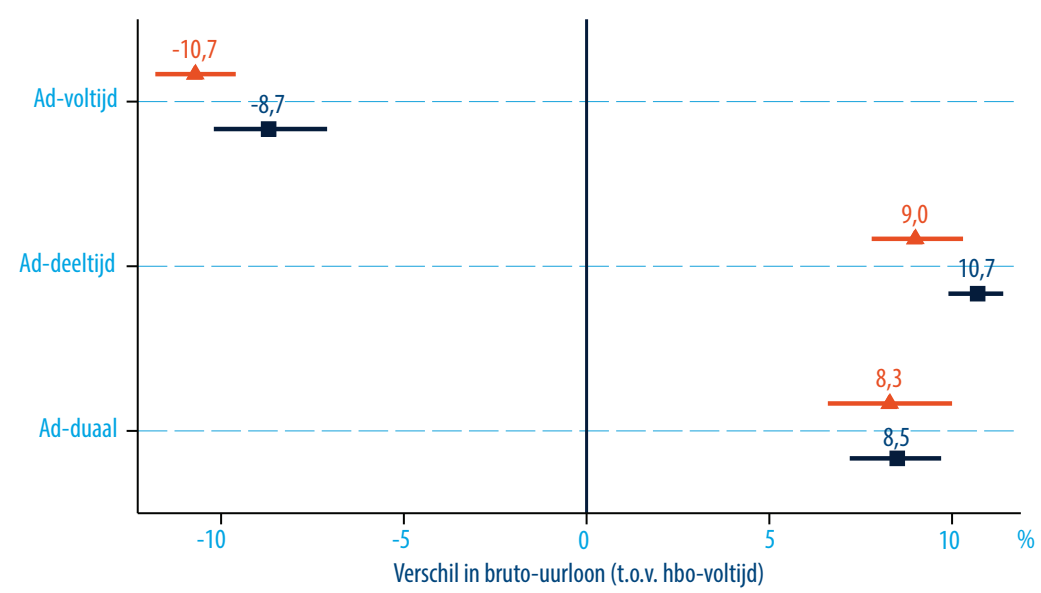

$\triangle \mathrm{DUO} / \mathrm{SSB}$

- HBO-Monitor

Model: kwantielregressie gecontroleerd voor leeftijd (lineair en kwadratisch), geslacht, migratieachtergrond, sector, jaar en examencijfer

Bron: DUO/SSB en HBO-Monitor 



\section{CONCLUSIE}

Het doel van dit rapport was tweeledig. In de eerste plaats was het de bedoeling om na te gaan welke plaats de in 2006 ingevoerde Ad-opleidingen innemen in het Nederlandse onderwijssysteem. Met behulp van zowel administratieve data van DUO en het SSB als surveygegevens van de HBO- en BVE-Monitor werd daarom zowel de in- en uitstroom als het rendement van Ad-opleidingen onderzocht en afgezet tegen hbo-bachelor en mbo 4 bol. Daarnaast tracht het rapport de kwaliteit van de Ad-data in de HBO-Monitor te evalueren. Hiervoor werd voor enkele beschrijvende statistieken en regressieresultaten een vergelijking gemaakt tussen de HBO-Monitor-data en de administratieve data.

In het schooljaar 2016-2017 volgde iets meer dan 3\% van het totaal aantal hbo-studenten een Ad-opleiding. Ongeveer de helft van hen koos daarbij voor een deeltijd of duaal programma. Ondanks dat het aantal Ad'ers door de tijd heen lijkt toe te nemen (met name in voltijd trajecten), wijst het beperkte aantal inschrijvingen erop dat dit opleidingstype wellicht te lijden heeft onder een geringe bekendheid bij studenten, leraren en studieloopbaanbegeleiders. De groep Ad'ers blijkt verder voornamelijk geclusterd te zijn in slechts enkele hogescholen en in de sectoren Economie, Zorg en Welzijn en Maatschappij, Taal en Kunst. Een belangrijk verschil met hbo-bachelor en mbo 4 bolstudenten is wel dat er in verhouding weinig Ad'ers een zorggerichte opleiding volgen.

Ad-opleidingen worden relatief vaak gekozen door personen die reeds een baan hebben en zich willen om- of bijscholen. Dit uit zich bijvoorbeeld in de vaststelling dat Ad-gediplomeerden gemiddeld drie jaar ouder waren dan hbo-bachelorgediplomeerden wanneer zij aan hun opleiding begonnen. Het leeftijdsverschil verkleint echter wanneer enkel afgestudeerden van een voltijd programma worden vergeleken. Verder blijkt dat het aandeel vrouwen dat een Ad-opleiding volgt de afgelopen jaren stelselmatig is toegenomen. Onder de studenten in een voltijd programma is bijna twee derde vrouw.

De instroom in voltijd Ad-opleidingen bestaat voor de helft uit mbo 4-gediplomeerden die rechtstreeks na hun mbo-opleiding aan een Ad beginnen. Dat is meer dan dubbel zoveel als bij voltijd hbo-bacheloropleidingen. Bovendien neemt dit aandeel door de tijd heen toe. De populariteit van de Ad bij mbo 4-gediplomeerden bevestigt de relevantie van dit nieuwe opleidingstype voor het behalen van de doelstelling van de 
Nederlandse overheid om meer mbo 4-gediplolmeerden in het hoger onderwijs te krijgen. De instroom in deeltijd Ad-opleidingen bestaat daarentegen voor meer dan de helft uit werkenden. Ook bij de duale Ad vormen werkenden een belangrijk deel van de instroom.

Ongeveer twee derde van de personen die starten met een voltijd Ad-opleiding maakt deze niet af, in tegenstelling tot ongeveer $50 \%$ van de hbo-bachelorstudenten. Dit komt neer op een studierendement van de voltijd Ad van 34\%. Ad'ers uit deeltijd en duale opleidingen hebben daarentegen een studierendement van iets meer dan 50\%. Van de voltijd Ad'ers die stoppen met hun opleiding stapt tevens ongeveer een kwart over naar een andere opleiding.

Verder is ook de arbeidsmarktpositie en het rendement van Ad-opleidingen in kaart gebracht. Om vertekening door de hogere leeftijd en grotere arbeidsmarktervaring van Ad-gediplomeerden te vermijden, is hier in de analyses rekening mee gehouden. De kernbevindingen met betrekking tot de arbeidsmarktuitkomsten van Ad-opleidingen laten zich als volgt samenvatten:

- Het loonrendement van (voltijd) Ad-opleidingen situeert zich twee en vier jaar na diplomering tussen dat van mbo 4 bol en hbo-voltijd. Daarmee positioneert de Ad zich tussen kwalificatieniveau 4 en 6, wat precies de opzet was van de Ad. Concreet verdienen gediplomeerden van Ad-voltijd gemiddeld $11 \%$ minder dan hbo-voltijd en $12 \%$ meer dan mbo 4 bol (voltijd). Ad-deeltijd en -duaal verdienen twee jaar na afstuderen gemiddeld bijna 10\% meer dan hbo-voltijd, maar na vier jaar is dit verschil met ongeveer de helft afgenomen.

- Gediplomeerden van Ad-voltijd hebben 2 procentpunten minder kans om twee jaar na diplomering een baan te hebben dan gediplomeerden van een voltijd hbobacheloropleiding. Ad-deeltijd en -duaal hebben daarentegen ongeveer 10 procentpunten meer kans op werk dan hbo-voltijd, wellicht als gevolg van de combinatie van studie en werk. Mbo 4 bol heeft zowel twee en vier jaar na afstuderen daarentegen een aanzienlijk kleinere kans op een baan.

- Gediplomeerden van Ad-voltijd hebben een kans die ongeveer 15 procentpunten groter is dan gediplomeerden van hbo-voltijd en mbo 4 bol om anderhalf jaar na afstuderen onder hun opleidingsniveau werkzaam te zijn. Bij Ad-deeltijd en Ad-duaal is die kans nog iets groter. Ook hebben voltijd Ad'ers gemiddeld 5 procentpunten meer kans om buiten hun opleidingsrichting te werken. De relatieve onbekendheid van de Ad is hier vemoedelijk een van de oorzaken van.

- Qua aantal gewerkte uren nemen Ad'ers een tussenpositie in. Gediplomeerden van Ad-voltijd werken twee jaar na diplomering gemiddeld 2 uur per week minder dan gediplomeerden van hbo-voltijd, en afgestudeerden van mbo 4 bol (voltijd) werken ongeveer 10 uur per week minder. Na vier jaar is het verschil in gewerkte uren tussen Ad-voltijd en hbo-voltijd verdwenen. Mogelijk worden de resultaten betreffende de arbeidsduur deels gedreven door bewuste keuzes, en hoeft een kleinere arbeidsduur daarom niet noodzakelijk te wijzen op een lager rendement. 
- Met betrekking tot de kans op een vaste aanstelling vinden we anderhalf jaar na afstuderen geen significant verschil tussen Ad-voltijd en hbo-voltijd.

- De kans dat gediplomeerden van Ad-voltijd anderhalf jaar na afstuderen een baan hebben die minder eigen vakkennis vereist dan ze bezitten, verschilt niet significant van de kans voor gediplomeerden van hbo-voltijd. Afgestudeerden van Ad-deeltijd en Ad-duaal hebben daarentegen respectievelijk 8 en 5 procentpunten meer kans op werk waar eigenlijk minder eigen vakkennis voor nodig is dan ze hebben.

- De studietevredenheid van Ad-voltijd-afgestudeerden verschilt anderhalf jaar na afstuderen niet significant van hbo-voltijd-afgestudeerden. Daarbij werd studietevredenheid gemeten als 1) de kans om achteraf gezien opnieuw voor dezelfde opleiding te kiezen, 2) het oordeel over de mate waarin de opleiding voorbereidde op de arbeidsmarktintrede en 3 ) het oordeel over de mate waarin de opleiding voorbereidde op de verdere ontwikkeling van kennis en vaardigheden. Ad-deeltijd en Ad-duaal scoren met betrekking tot het eerste en laatste element wel significant positiever dan hbo-voltijd, en over de twee laatste elementen is Ad-voltijd gemiddeld positiever dan mbo 4 bol.

Een vergelijking van Ad-data uit de HBO-Monitor-data met de administratieve Ad-data leert dat de HBO-Monitor, ondanks het relatief beperkte aantal Ad-observaties, over het algemeen een vrij waarheidsgetrouw beeld van Ad-gediplomeerden geeft. Oudere Ad-gediplomeerden lijken wel meer geneigd om de vragenlijst in te vullen, waardoor zij enigszins oververtegenwoordigd zijn in de data. Die vertekening zou echter opgelost kunnen worden door ook voor Ad-afgestudeerden een weegfactor te berekenen. Voor het financiële rendement van een Ad-opleiding maakt het weinig verschil of het geschat wordt met de HBO-Monitor-data dan wel met de administratieve data. Op basis van deze resultaten lijkt de conclusie gerechtvaardigd dat de HBO-Monitor als een tamelijk betrouwbare bron kan worden beschouwd als het om afgestudeerden van Ad-opleidingen gaat. Het verdient wel aanbeveling om in de toekomst door middel van een weegfactor eventuele afwijkingen van respresentativeit recht te zetten. Gegeven de populariteit van deeltijd en duale Ad-programma's en hun andere leeftijdssamenstelling zou bovendien overwogen kunnen worden een aparte Ad-Monitor vorm te geven.

Samenvattend kan gesteld worden dat Ad-gediplomeerden even tevreden zijn over hun studie, evenveel kans hebben op een vaste aanstelling en iets minder kans maken op een baan dan hbo-bachelorgediplomeerden. Bovendien gaat het dan om een baan die gemiddeld $10 \%$ minder betaalt en zich gemiddeld $15 \%$ vaker onder het opleidingsniveau bevindt. Als gevolg van de eventueel gradueel toenemende bekendheid bij werkgevers zouden deze verschillen echter anders kunnen uitpakken in de toekomst. Het is dan ook aan te bevelen om de ontwikkelingen rond Ad-gediplomeerden nauw te blijven volgen. 



\section{BIJLAGE}

\section{Mbo 4-studenten}

Figuur $\mathrm{X}$ en $\mathrm{Y}$ hebben betrekking op het totaal aantal mbo 4-studenten en komen uit een bestand van de DUO-website. DUO heeft geen publiek toegankelijke data over eerstejaars mbo 4-studenten.

\section{FIGUUR X Aantal mbo 4 bol-studenten naar opleidingsvorm (2006-2017)}

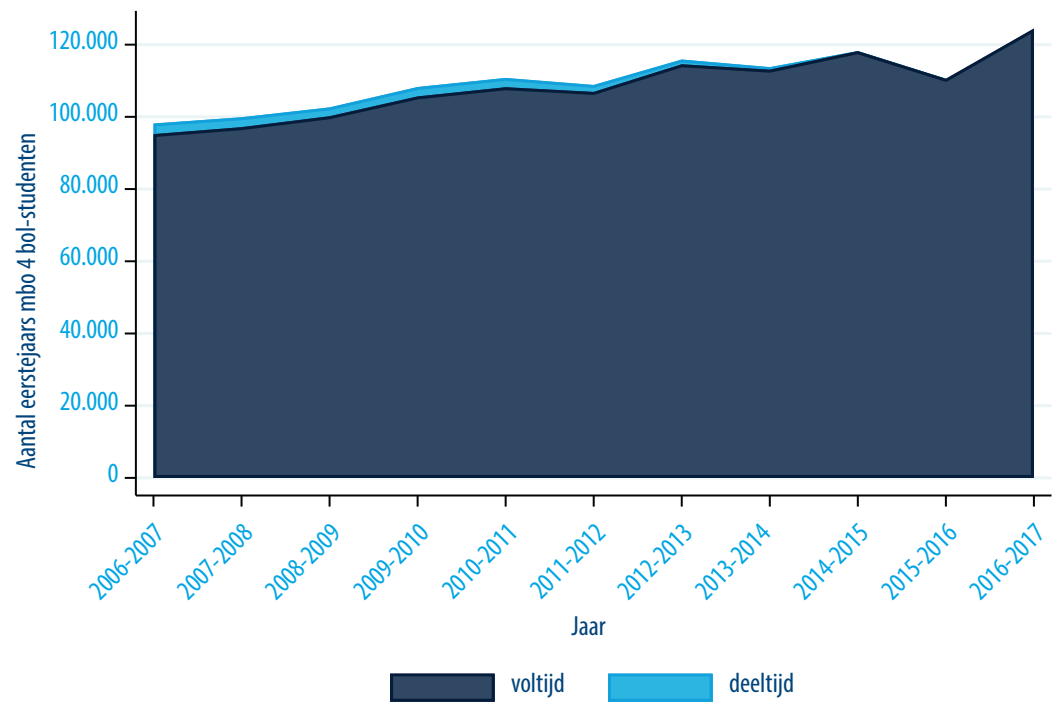

Bron: DUO 
FIGUUR Y Aantal eerstejaars mbo 4 bol-studenten naar opleidingssector (2016-2017)

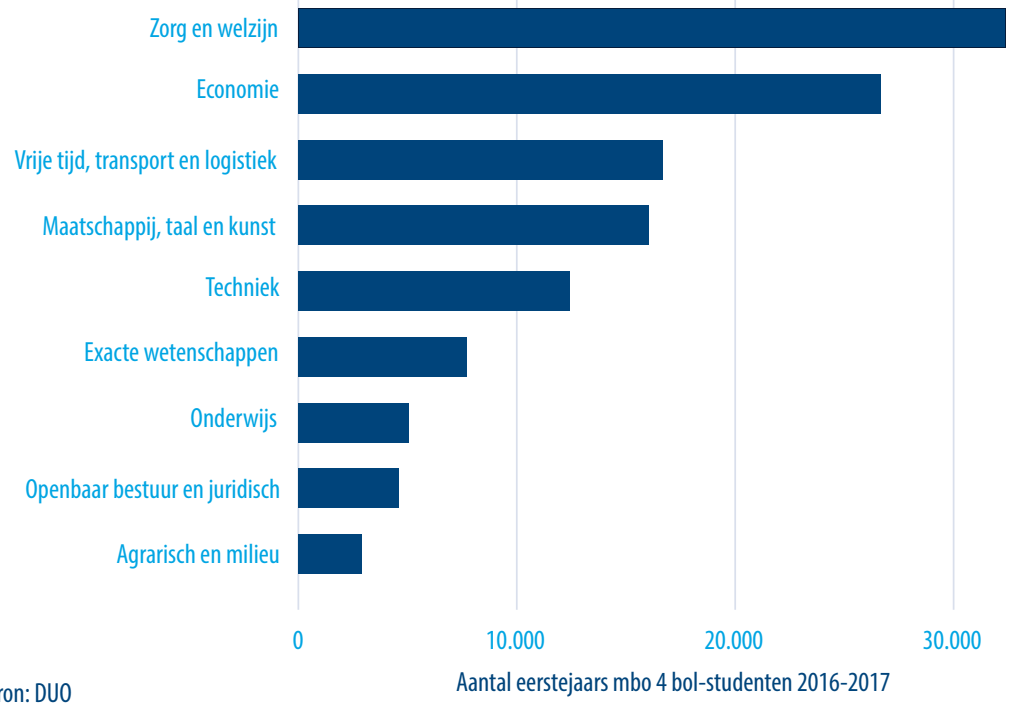

Analyse bruto-jaarloon

Figuur 29 bevat de schattingsresultaten voor het bruto-jaarloon, en toont dat ook op jaarbasis de relatieve positie van het financiële rendement van Ad-voltijd twee en vier jaar na afstuderen tussen dat van mbo 4 bol (voltijd) en hbo-voltijd ligt. Opvallend is dat werkende gediplomeerden van mbo 4 bol (voltijd) een mediaan jaarsalaris hebben dat meer dan 50\% kleiner is dan dat van hbo-voltijd. Dit wordt in belangrijke mate verklaard doordat mbo 4 bol-gediplomeerden gemiddeld minder uren werken (zie Figuur 26). 
FIGUUR 29 Resultaten voor het bruto-jaarloon (twee en vier jaar na afstuderen, administratieve data)

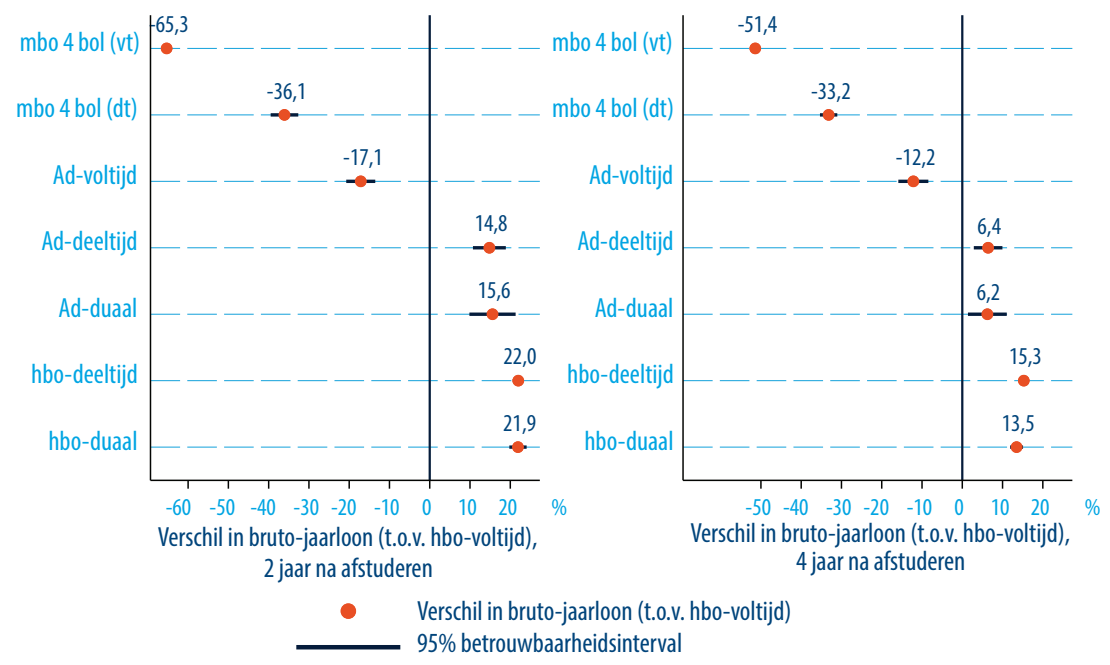

Model: kwantielregressie gecontroleerd voor leeftijd (lineair en kwadratisch), geslacht, migratieachtergrond, sector en jaar

Bron: DUO/SSB 
